\title{
FinTech Innovations and Islamic Banking Performance: Post pandemic Challenges and Opportunities
}

\author{
Abdul Aziz Abdul Rahman ( $\sim$ a.abdulrahman@ku.edu.bh ) \\ Kingdom University https://orcid.org/0000-0003-4967-6223 \\ Habeeb Ur Rahiman \\ Kingdom University \\ Abdelrhman Meero \\ Kingdom University \\ Ahmed Rashad Amin \\ Kingdom University
}

\section{Research}

Keywords: FinTech, Innovations, Islamic banks, performance, Sustainability

Posted Date: February 1st, 2022

DOI: https://doi.org/10.21203/rs.3.rs-1272120/v1

License: (c) (i) This work is licensed under a Creative Commons Attribution 4.0 International License. Read Full License 


\section{Abstract}

Current research aims to investigate the role of financial technology (Fintech) during pandemics on Islamic financial institutions and banks' performance. The study identified measures of lockdown executed by numerous countries across the world that have also indicated the significance of leveraging technology and establishing a livelier Islamic finance industry. The results and data analysis identified adoption of greater digitalization and incorporation of fintech strengthens the spirit of the industry in a more unstable ecosystem and challenges like pandemic and open another new opportunity for growth. However, recent financial years have shown that there is room for expansion and growth, especially for Sukuk issuance, by guidelines and regulations, and ease and velocity of implementation. The results also suggested various indications on the effect of financial technology reform on the Islamic banks' growth significantly with the adoption of the Fintech revolution. Since the performance of Islamic banking proved to be better in certain aspects compared to conventional banking, this study suggests industry adopt paradigm change and development of financial technology to enhance the global market.

JEL: F36, G24, Q55, Q56

\section{Introduction}

Islamic banks are currently a major partner in the field of banking and finance. Contrary to conventional commercial banks, Islamic banks invest money in a manner consistent with Islamic rules and principles. Islamic banks are currently spread in many countries of the world, especially in the Arab Gulf countries, and they are constantly working on developing financial systems and making them more flexible and responsive to customers' requirements. Islamic transactions are not limited to the Gulf and Islamic countries, but also include other countries such as Japan, South Korea, Britain, and other countries (Gözübüyük, Kock and Ünal, 2020). Studies indicate that more than 600 Islamic banks are currently operating around the world, and they are spread over 75 countries. Islamic transactions are distinguished in that they have exceeded the normal transactions of banks, as Islamic banks are currently working on issuing Islamic Sukuk that are required to implement some large projects. The rapid spread of Islamic banks around the world has made them at the forefront of competition with usurious banks, especially regarding the use of financial technology in the implementation of operations as well as in providing services to customers in the best and fastest ways. Because of the rapid spread of Islamic banks, interest in financial innovations for these banks has been a necessity and not an option to keep pace with the development in the world of financial technology and the ability to stay in the market under the strong competition that they are exposed to by usurious banks (Laallam et al., 2020). The Islamic banking sector has witnessed a great development in recent years due to the great development that has occurred in financial technology, especially Islamic financial technology. This development was accompanied by a significant increase in the demand for Islamic banking products by banks and other financial institutions, whether Islamic or conventional and at the global level, especially those distributed in the Arab Gulf states, the United States, and Asia (Ramli, Marzuki and Nazri, 2020). Fintech is a financial technology 
innovation used in financial transactions of various banks such as money transfer, currency exchange, providing services to customers, and other banking transactions.

Recent years have witnessed great developments in the production and marketing of financial technology, with the United Kingdom topping the list of the top ten countries in the field of financial technology production, followed by Singapore, New Zealand, the Netherlands, Hong Kong, Sweden, and Canada, Denmark, Ireland, and Switzerland. As for the countries that have shown great interest in making use of financial technology to develop their banking sector, especially the Islamic banking sector, Indonesia topped the list as the largest consumer of financial technology, followed by Turkey and the Gulf Cooperation Council countries (Shabbir et al., 2020). Despite the limited electronic services provided by banks in the field of digital technology, such as cash transfers and other electronic services provided to customers, the banking sectors, especially Islamic ones, have been able to increase the efficiency of their banks through continuous improvement of their electronic services, which has helped enhance their competitiveness. Studies indicate that more than $78 \%$ of banks operating in the Gulf countries seek to work continuously to improve their electronic services provided to their customers by attracting more digital technology. Statistics also indicate that more than $40 \%$ of global financial technology is used in the Gulf countries (Rehman et al., 2020).

\section{Literature Review}

\section{Role of Islamic FinTech in supporting Islamic banks:}

The great development in the production of financial technology and the emergence of many emerging companies in this field led to a great development in the financial sector, especially the banking sector. These new developments in the world of financial technology have shown profound changes in the banking sector, enabling this sector to enhance its competitiveness by relying on multiple digital technologies in the performance of its services such as artificial intelligence (Al), Internet of things (IoT), robotic process automation (RPA) and blockchain, which enabled the banking sector provides a variety of services in the field of money transfer and wealth management, in addition to many other services such as insurance services, e-commerce, and digital currencies (Mohd Ali, Shafii and Shahimi, 2020). Financial technology has created a new reality that has accompanied the harmony of many companies such as telecommunications companies, media, e-commerce, and other technology companies (Abdullah, Hassan and Kassim, 2020). After a short period of hesitation, the process of competition between banks, especially the large ones, started by allocating huge investments to develop and modernize their digital infrastructure and develop their digital platforms via the Internet and include new applications to become more accessible and faster in communication with customers, and some of them launched digital banking to respond to changing dynamics, enabling them to provide a better banking experience to their customers (Siti-Nabiha and Norfarah, 2020).

This reality has posed a great challenge to Islamic banks and Islamic financial institutions alike, as it has forced this sector to make fundamental changes in the way services are performed, through the need to 
use new applications of financial technology, and work to invest in this digital technology as a necessary infrastructure in the great competition that the banking sector is witnessing at the global level has remained (Khairulanuwar and Chuweni, 2020). Also, the banking sector is required to work on the continuous development of human resources to be able to keep pace with this new world of technology. Many Islamic banks believe that customers are not ready to replace their Sharia-based services with fintech innovations that are still being fully compliant with Sharia, and therefore they do not expect customers to grow in anger over the inaction and lack of many of them seeking to adopt products of financial technology. Many CEOs of Islamic banks believe that opening to financial technology requires high cost and highly skilled human resources, especially as it is developing at a high speed. In addition, it is likely to negatively affect cyber and information security, and budget constraints, but the emergence of a new type of financial technology under the name of Islamic financial technology in many countries of the world is gradually growing and expanding, and it is known as all contemporary digital financial applications that can be used In the Islamic banking and financial services sector, and it does not intersect with the purposes of Islamic Sharia, and leads to the development of new business models, based on technology, to enhance the objectives of Sharia in the economic, environmental, financial and social fields, and to provide better services to Islamic banking customers, in terms of product quality and speed of service delivery (Ali, Ahmad and Kamaruddin, 2020). It provides easier and less costly access to Islamic financial services, keeping pace with the aspirations of the new generation, and achieving financial inclusion to alleviate poverty and establish social justice (Tarique et al., 2020). It has achieved impressive results, proving that the effective use of Islamic financial technologies coupled with innovative business models, in light of a favorable regulatory, legislative and supervisory environment that is consistent with the purposes of Islamic Sharia, and qualified human resources, enhances confidence in Islamic finance and banking, and leads to an increased demand for its products, and the expansion of its investments, especially that financial technology has raised the ceiling of competition between financial institutions to provide the best and fastest services, and the pattern of change in the market has become very fast (Muhammad, Suluki and Nugraheni, 2020). In light of the new reality, many Islamic banks have realized the importance of embracing Islamic financial technology and have designed their development plans to include innovative banking solutions that are in harmony with Islamic financial technology products and to meet the changing needs of their customers, especially young people, and seek to enhance mutual trust with them. For example, the Islamic Bank of Dubai has designed a digital strategy entitled "Ready for the New", about which its CEO Group says: "We live in a different world almost entirely led by the Fourth Industrial Revolution, which is a digital journey that connects human behavior with the Internet of Things, and that is why we, as a leading Islamic bank, have to Correct the role we play in society, and in the daily lives of our customers, to keep pace with this change". As well as Bahrain Islamic Bank, Al Baraka Bank, and other Islamic banks in Bahrain (Aziz et al., 2020).

In addition, the repercussions of the Corona pandemic prompted Islamic banks to accelerate their digital strategy and to spread and adopt Islamic financial technology innovations at a pace that was not possible before the growing repercussions of the Corona pandemic. The adoption of Islamic financial 
technology innovations in the Islamic banking sector and their continued development by Islamic financial engineering, and support for the innovation of new financial technology products that are compatible with Islamic Sharia, will give the Islamic financial and banking sector a new impetus to move forward, allow it to improve its product offerings, and enable it to compete with the financial and banking sector not only on the level of the Islamic world but also on the global level.

\section{Digital innovations in banks:}

Day by day, dependence on digitization and financial technology is increasing in all sectors around the world, especially the banking sectors, as this rapid development falls under the so-called Fourth Industrial Revolution. Reliance on digital and financial technology has increased significantly with the spread of the Corona pandemic, which began in China in late 2019 and later spread to all parts of the world, as a result of this, the traditional work practices were temporarily dispensed within most sectors around the world, especially the banking sectors, and the shift to Working remotely, and with that was accompanied by the banking sectors converting most banking services to electronic services to complete most customer services through mobile applications, as well as money exchange machines distributed widely in alleys around the world (Buallay et al., 2020). With the increasing demand for financial technology for banking sectors compared to other sectors, it has become imperative for the global banking sector to adapt to these increasing developments so that the banking sector can play its role effectively (Hassan et al., 2020). The Gulf Cooperation Council (GCC) countries are considered pioneers in the field of financial technology, as they are among the first countries that accelerated investment in financial technology as one of the sources of economic diversification in the region. The Kingdom of Bahrain is one of the pioneers in the field of investment in financial technology, as the Kingdom of Bahrain is witnessing renewed financial technology projects that provide the banking sector with various banking services in line with the increasing demand for them through the provision of biometric ATMs distributed throughout the Kingdom (Utomo et al., 2020).

In this regard, the Governor of the Central Bank of Bahrain issued Resolution No. (43) of 2017 regarding the experimental environment for financial technology, and in May 2017, the Bank issued a final paper on the "Experimental Regulatory Environment" (Syachfuddin and Rosyidi, 2020). On the bank's website, the paper included setting a framework for the use and development of the financial technology industry in an organized manner. The bank's board of directors also issued a decision to establish a unit specialized in the field of financial technology and innovation (Shaik Mohammed and Waheed, 2019).

\section{Harmony between FinTech and artificial intelligence in enhancing the banks' performance:}

Digital and financial technology have constituted one of the main pillars of the banking sector, as most of the clients of this sector accomplish most of their transactions through digital applications that are widely spread (Shaikh et al., 2019). Financial technology and artificial intelligence constituted a real starting point for restructuring financial services and transforming them from traditional services to services of an electronic nature. Fintech has contributed to reducing customer service time as well as reducing the cost of providing these services and increasing their accuracy. The great shift towards 
digitization and the increasing use of financial technology requires the banking sector to put in place supervisory systems capable of ensuring the security and integrity of all financial transactions that arise between banks and stakeholders. This development argues that financial technology represents opportunities and challenges at the same time for various banks and financial institutions (Alziyadat and Ahmed, 2019). The use of artificial intelligence and financial technology in the banking sectors has reduced the costs of completing financial transactions as well as improved the performance and profitability of banks as well. The great advantages offered by financial technology and artificial intelligence have shaped the pursuit of many sectors, especially financial and banking, to increase investment in artificial intelligence tools and modern financial technology (Dharani, Hassan and Paltrinieri, 2019). Studies indicate that artificial intelligence will contribute about $\$ 15.7$ trillion to the global economy in 2030. On the Arab level, the region's share is expected to reach $2 \%$, as artificial intelligence applications will contribute about $\$ 320$ billion to the economy of the Middle East region by 2030 , equivalent to $11 \%$ of the GDP. A pilot regulatory environment is defined as a safe place where companies can test financial products and services with advanced technologies without the burden of laws, regulations, and licenses (Mohd-Rashid and Tajuddin, 2019; Zaki et al., 2019).

Emerging financial technology companies have revolutionized the field of financial systems at the global and Arab levels, as they were able to provide a large package of financial services that changed the face of financial transactions and transformed them from traditional transactions using paper to entirely electronic transactions, such as remittances, loans, depositing checks, withdrawing and depositing funds, and obtaining On account statements, insurance services, crowdfunding and many other financial services that are now available in many financial institutions and the banking sector alike (Ho and MohdRaff, 2019; Kabir Hassan, Rashid and Aliyu, 2019). Banks and financial institutions have sought to adopt many of these modern technologies in the world of financial technology to take advantage of their capabilities in carrying out their work and to catch up with the development and competitiveness that has become a reality in the new financial environment (Boudt, Raza and Wauters, 2019). Hence, it has become imperative in the modern financial technology environment to have legislative, supervisory, and regulatory frameworks that allow the operation and development of new financial technology and financial artificial intelligence in line with the requirements of each financial institution. Framing these financial technologies and artificial intelligence systems within legal controls would enable the relevant supervisory and regulatory authorities to work to mitigate the risks that could arise from operating these systems while maintaining financial stability and financial soundness (Hasim, Ariffin and Zakaria, 2019). Since financial technology has become one of the most important financial applications with widespread and widespread use in the financial and banking circles, many emerging companies in the field of financial technology have integrated operations of artificial intelligence and financial technology in the traditional operations of many financial institutions and banks to help these institutions improve performance Its operations are faster and safer. Financial technology has become one of the most important technology sectors used globally, as it performs many special tasks such as credit rating operations, fraud detection, manipulation, and wealth management, in addition to many of the tasks previously mentioned (Rosman, Haron and Othman, 2019). 
In addition to the above, it has become possible to use artificial intelligence algorithms to predict the many changes that occur in the stock markets and analyze these changes as well as give insight into the economy as well as better understand the habits and tastes of consumers (Othman and Tahir, 2019). Robotic Process Automation (RPA) technology is also used to operate many financial and accounting systems more quickly and efficiently, such as processing financial operations related to accounts receivable and creditors, as well as preparing financial reports faster and more accurately and presenting them to decision-makers in a timely and appropriate form. In addition to the previous duties of financial technology, it has also become used in the field of creating marketing strategies for banks to help them improve their operations and enhance their competitiveness (Hanif, 2018; Kuran, 2018). On the other hand, the huge volume of financial data that is operated under the new financial technology has made this data more vulnerable to the risks of piracy and theft, which prompted the companies producing and operating these financial systems to find means of protection for this data that would protect sensitive financial data and stop piracy and potential electronic attacks.

\section{RegTech and Impact of regulations on Islamic banks development}

For the legislative framework of the newly developed financial technology, most Arab countries have shortcomings in legislation for these new tools, especially in the founding legislation, including general legislation related to electronic transactions, electronic identification, and electronic signature. The failure to pass these legislations does not allow unleashing of electronic financial and banking transactions, nor the launching of innovations and developments in electronic transactions. The legislative framework is required to keep pace with technological developments and protect private and public interests. To ensure the security of operations carried out by Islamic banks based on financial technology, it is necessary to reconsider the existing legal and legislative structure by working to include new legislation that guarantees the security of data and operations based on financial technology, such as payment systems and services, which helps Islamic banks manage legal contracts Ensure continuous monitoring and control of operations to protect the Bank and its customers (Anagnostopoulos, 2018; Karim, et al., 2021).

It is also necessary for Islamic banks to keep pace with developments in the use of financial technology by setting regulations, policies, and procedures that regulate the internal work in them, whether for developing the skills of workers in these banks or for monitoring operations that are carried out using this technology and the safety and security procedures followed in these banks or for Providing electronic services that fulfill customers' desires and expectations in a safe, efficient and cost-effective manner, as well as the security that must be provided to investors. Fintech has fulfilled this need by providing many innovative and secure electronic financial services. There is no doubt that this would keep Islamic banks in the circle of competition with other traditional banks in the face of modern financial companies that adopt this type of technology (Anagnostopoulos, 2018; Karim, et al., 2021).

\section{Global and Arab investments in FinTech:}

Global investment in FinTech reached \$98 billion across 2,456 transactions in the first half of 2021, far exceeding the total investment in 2020 of $\$ 121.5$ billion across 3,520 transactions. Consequently, global 
FinTech financing across mergers and acquisitions, private equity, and venture capital rose to a new high in the first part of 2021, based on KPMG's Pulse of Fintech, a semi-annual report on fintech investment trends. Overall investment in FinTech is expected to remain high during the second half of 2021 compared to previous periods(El Ouadghiri and Peillex, 2018). With the increase in digital transactions, it is expected to increase the demand for new models of banking services, and B2B services, as well as an increase in the demand for electronic control systems and cybersecurity in light of the escalation of electronic attacks globally. In terms of cybersecurity, global investment also achieved a large number during the first half of 2021, rising from $\$ 2.2$ billion in 2020 to more than $\$ 3.7$ billion during the first half of 2021. European and the Middle East and African investments in This field amounted to $\$ 39.1$ billion in fintech during the first half of 2021 (Mohammed and Abu Rumman, 2018).

\section{Challenges facing FinTech and Al companies in Arab Countries:}

One of the most important challenges facing the spread of financial technology companies in the Arab countries is related to gaining customers' trust due to the concerns these customers have regarding fraud and piracy, especially in the absence of clear protections that protect stakeholders from fraud and piracy that they face when dealing with electronic financial services. in many Arab countries. In addition to the above, we also note the absence of legal legislation that would combat electronic crimes in many Arab countries, as it is available in some Arab countries such as Algeria, Egypt, Oman, Morocco, Qatar, Tunisia, and the United Arab Emirates. Not to mention the difficulties facing the establishment of financial technology companies due to the nature of the laws regulating the establishment of financial services companies, as well as the limited capital ready for such projects (Javaid and Al-Malkawi, 2018).

Among these challenges is also the increasing difficulties that these companies face in meeting the requirements of compliance with the laws related to anti-money laundering and combating the financing of terrorism. In addition to concerns related to electronic fraud and piracy, the artificial intelligence sectors in the Arab region face major problems concerning the ability to access information in light of the weak infrastructure of communication networks and the Internet and their low speed, as most financial companies and banks in the Arab region need to be restructured And a new infrastructure that allows it to take advantage of artificial intelligence techniques, and this, of course, require large investments that are often difficult to secure. The second challenge facing financial institutions and banks in the Arab region if they tend to benefit from artificial intelligence techniques is the limited skills and expertise needed in the field of financial technology and artificial intelligence, as there are no qualified professionals in the field of artificial intelligence and digitization who can link the infrastructure of their institutions to the process of digital transformation. around the world (Elhaj, Muhamed and Ramli, 2018).

\section{Financial technology and its impact on money transfer:}

Considering the rapid development of mobile smartphones and the huge capabilities that they provide for their users, and the availability of the Internet faster, the user is waiting for better services and easier ways to provide all his daily needs, which has helped to increase the intensity and fierce competition. This led to the decline of traditional business models that favor innovative areas, and survival in the market and 
ensuring long-term continuity depends on comprehensive support (Wediawati et al., 2018). There is no doubt that all businesses have moved towards automation and societies towards cashless and digital. Recently, modern technological techniques, such as the blockchain, have achieved great success in the areas of money; Where it was able to issue digital money for central banks, which led to an increase in electronic transactions; Due to the entry of the public sector and its support for digital. Modern technological techniques have also been able to transfer and lend money quickly, which may exceed the banking mechanisms deployed around the world. In terms of speed, cost, and ease (Ghosh, 2018).

\section{Financial technology and its role in promoting economic growth:}

Fintech technologies are modern innovations aimed at competing and developing traditional methods of providing financial services. These technologies depend entirely on the Internet to accomplish the tasks assigned to them (Noor, 2018). Many financial technology companies have succeeded in providing many financial services that have been widely accepted in the financial circles and their services, especially about payments, remittances, and digital currencies, in addition to other services such as insurance services, wealth management, and others. Given the importance and sensitivity of financial transactions, the importance of having legal and legislative frameworks capable of reducing the risks of electronic theft and piracy in a manner that ensures information security and financial stability has emerged (Klein, Weill and Godlewski, 2018).

Technological innovations have already made banking and commerce through smart apps, for example, the only smartphone app for stock trading (Robinhood) that charges no transaction fees, and lending sites (Prosper) and (Lending Club) which promised to reduce interest rates within Loan competition operations, as well as banking services and stock trading via smartphones. In commodity markets and digital portfolios such as Apple and Google, which are developing e-portfolios systems, financial advisory and robot-advisory sites such as (Learn Vest, Betterment) and money management tools such as (Mint) and (Level). These changes related to technology modernization, credit generation, risk transfer, and equity have increased the credit available to borrowers while finding more efficient ways to raise capital at lower costs (Ahmad, Rais and Shaik, 2018). Cybersecurity threats remain the most significant threat to financial services today. Studies show that enhancing internet and data security is very important for FinTech companies. Education and awareness of technology solutions are critical to preventing vulnerabilities in the financial system. All FinTech companies have some security or privacy issues associated with web applications and APIs. According to research by ImmuniWeb, a global technology company based in Geneva, Switzerland, which specializes in security testing implementation technologies, $98 \%$ of global fintech startups are vulnerable to major cyberattacks, including fraud and application security attacks on mobile and web. The research also indicated that $100 \%$ of fintech companies have some security or privacy issues associated with web applications, APIs, and subdomains. Cross-site scripting (XSS), display of sensitive data, and security misconfiguration are major website weaknesses, and all Fintech's mobile apps have at least one vulnerability, and this is the most significant cybersecurity risk for the fintech industry today (Masih, Kamil and Bacha, 2018). 


\section{The role of financial technology in developing the performance of Islamic banks:}

Islamic banks have become at present mainly present in the financial markets, whether in Islamic countries or other countries. Whereas, these Islamic banks provide diverse and competitive services to traditional banks, especially about investing investors' money in a manner that is compatible with Islamic Sharia, thus avoiding investors from engaging in usury and what is contrary to Islamic Sharia (De La O González, Jareño and El Haddouti, 2018). Islamic banks have constituted an important alternative to usurious traditional banks, as they have contributed to the development of the financial system of banks in many countries, especially countries with an Islamic character. In the year 2021, statistics indicate that there are more than 600 Islamic financial institutions distributed in about 75 countries around the world. These institutions include stock exchanges, takaful institutions, banks, and insurance institutions. The Islamic financial system has extended to include many other countries besides Islamic countries such as South Korea, Japan, and Britain, where banks in the mentioned countries have resorted to opening many windows for Islamic transactions, as they sometimes resorted to issuing Islamic bonds for the implementation of huge infrastructure projects (Adam, Al-Aidaros and Ishak, 2018).

The successes achieved by Islamic banks constituted a great challenge for these banks, as it made them in direct competition with the traditional usurious banks spread around the world. The aspects of competition were particularly evident in benefiting from modern financial technology innovations in the field of customer service and the completion of financial transactions in a way that increased the efficiency of these banks and improved their services significantly (Causevic, 2018). Recent innovations in the field of financial technology have constituted a major turning point in the development of the global financial system and the improvement of the competitiveness of banks, especially Islamic banks. Among the Islamic countries that have been interested in benefiting from the innovations of modern financial technology in developing the performance of their Islamic banks are Indonesia, Malaysia, and the Gulf countries, where these banks were able to develop the performance of their banks by providing their products and services that rely mainly on digital technology to complete transactions related to these products and services in a way that competes strongly with banks traditional usurious. According to a study conducted by EY, results showed that $78 \%$ of banks in the Gulf countries are seeking to adopt more financial technology to improve their electronic services (Murdayanti and Puruwita, 2018).

\section{Role of FinTech innovations and Al in developing the future of banking services:}

Despite the many benefits of expanding the construction of financial technology and artificial intelligence, the safety and security of information have constituted a major obstacle to the continuity of innovation in this field without borders. Thus, it is necessary to balance the global trend towards technological innovations and the risks associated with this trend. Therefore, to ensure the integrity of these innovations and not turn into sources of fraud and piracy, the following points must be taken into account, especially in the Arab region:

a. The necessity for banks and financial institutions to develop legal frameworks for payment operations that contribute to the development of financial and technological products and help spread financial 
inclusion services by enabling marginalized segments to access the payment system.

b. The necessity of investing in modern technological technologies such as the blockchain in the context of developing electronic financial services to reduce the traditional methods of using cash.

c. The need for the various components of the banking and financial sector to pay attention to training employees on the mechanisms and techniques of financial technology and artificial intelligence, given their role in diversifying economic activity and developing banking work to become more responsive to the changing and multiple needs of the widest segments of dealers with this pioneering and vital sector.

d. Encouraging central banks, in keeping pace with artificial intelligence, and the process of transforming the financial and banking sectors from the stage of the traditional economy to the stage of the digital economy, coinciding with containing the risks of this transformation and its repercussions.

e,Increasing spending on artificial intelligence to improve banking services provided to customers, especially through electronic applications and technologies.

Regarding the legislative framework for the new electronic tools, most Arab countries have shortcomings in legislation for these new tools, especially in the founding legislation, including general legislation related to electronic transactions, electronic identification, and electronic signature (Puruwita and Murdayanti, 2018). The lack of adoption of these legislations does not allow unleashing of electronic financial and banking transactions, nor the launching of innovations and developments in electronic transactions. The legislative framework is required to keep pace with technological developments and protect private and public interests.

\section{Methodology}

The study has collected various figures and data's from highly reputed publications and institutions like Standard and Poor's 500, Bahrain Economic Development Board, World Bank, International Monitory Fund, Islamic Development Bank, Ernst and Young, Thomson Reuters, and Forbs.com etc. The data comprises from pre-Covid to post Covid with an estimation up to 2025. In line with literature review, study administered published data from Scopus and Web of Science database. The financial and numerical data collected from Bloomberg marketing data and various statistical tools applied to conceptualize in figure.

The paper also applied comparative index approach to analyze the conventional and Islamic banks performance during pre and post covid era. Data published in World health organisation's international classification of diseases, Labuan international business and financial center, and S\&P Global to analyze the performance and growth indices during pandemic.

\section{Results And Discussion}

\section{Performance of Islamic Finance in Fintech era}


The Islamic finance or Shari'a-compliant finance contains (Figure 1) Islamic banking, Islamic Bonds, Islamic Insurance and Islamic capital markets, Takaful, and other IFls (Razak et al., 2021). According to ICD-Refinitiv in 2020, there are more than 1526 Shari'a-compliant financial establishments were running businesses in 72 nations, regulated in 46 countries, with an expected to increase from US\$2.5 trillion in 2018 to US\$3.5 trillion during 2024 Islamic finance assets (Khan et al., 2018). Reports (Figure 2) state that the growth of Islamic financial assets, since 2012, from US\$ 1761 billion to US\$ 2875 billion and is expected to reach US\$ 2693 billion during 2024 (S\&P Global, 2021). The progress of $14 \%$ in global Islamic finance business assets was due in part to improved amounts of Sukuk issuance in the usual established traditional markets in South Asia and GCC (Khan and Rabbani, 2020). There is a significant contribution have made by Islamic funds to the growth of the industry (Kartiwi et al., 2018). The asset class grew 30\% in 2019, predominantly in the GCC, with new markets of Islamic exchange-traded funds (ETFs) in several countries and of environmental, social, and government (ESG) associated investment resources made accessible through digital media that attract in certain to millennials (Shaikh, 2020; Wasiaturrahma et al., 2020). Islamic banking is yet the biggest Islamic finance division with a share of 70\% (ICD, 2020) or USD 1.72 trillion in 2017 (S\&P Global, 2021), followed by Sukuk at USD 470 billion (18\%) (Labuan IBFC, 2020), other financial institutions at USD 140 billion (6\%) (Crossmark global, 2020), Islamic funds at USD 108 billion (4\%) (Standard \& Poor's, 2020)(S\&P Global, 2021), and Takaful at USD 46 billion (2\%) (ICD, 2020)(Elgadi and Yu, 2018).

Table 1

Top Ten Countries Global Average IFDI Values For 2020

\begin{tabular}{|llll|}
\hline & IFDI 2020 & QD & Rank \\
\hline Malaysia & 111 & 94 & 1 \\
\hline Indonesia & 72 & 27 & 2 \\
\hline Bahrain & 67 & 38 & 3 \\
\hline United Arab Emirates & 66 & 31 & 4 \\
\hline Saudi Arabia & 64 & 59 & 5 \\
\hline Jordan & 53 & 14 & 6 \\
\hline Pakistan & 51 & 18 & 7 \\
\hline Oman & 45 & 14 & 8 \\
\hline Kuwait & 43 & 48 & 9 \\
\hline Qatar & 38 & 28 & 10 \\
\hline QD: Quantitative development; IFDI: Islamic Financial Development Indicator \\
\hline
\end{tabular}

The global Islamic Finance Development Indicator (IFDI) (Table 1) delivers the industry's different participants with a comprehensive evaluation of the key components driving development in the Islamic finance industry. Around the world, it is the ultimate indicator of the state of the Islamic finance industry 
in 2020, with ranks offered for 135 nations (Figure 3). It represents certain indicators like Quantitative development, governance, awareness, etc., deemed to be the key drivers of growth in the trade. By quantifying variations in these indicators over time and throughout territories, the IFDI offers a crucial instrument in regulatory policy in the industry. The overall development of industries has been measured by the IFDI considering the depth of the ecosystem. Table encapsulates the present state of the global Islamic finance industry through various indicators and emphasizes its top-ranking nations as per the IFDI (IFD, 2020). The worldwide IFDI estimate for 2020 lingered constantly at 10.8 when averaging the Islamic finance development indicators across the 135 countries observed. Though there were changes in each of its five key indicators as Knowledge and Corporate Social Responsibility (IFD, 2020) changed greater from the year earlier, whilst Quantitative Development (ICD, 2020), Awareness, and Governance each dropped (The Economist Intelligence Unit, 2020). The similar was also the situation by country, a few of which enhanced while others dropped in value (Labuan IBFC, 2020). According to a recent report published by IFDI, 2021, the projected reach of the Islamic finance industry is $\$ 4.94$ trillion in 2025 . The study emphasized different trends during 2021 which include the growth of the digital bank and fintech industry controlled by countries like the Kingdom of Saudi Arabia, Bahrain, Malaysia, UAE, and Indonesia. The performance indicator depicts that the Southeast Asian countries Malaysia and Indonesia maintained their highest positions. As per IFDI's recent publication, double-digit growth has been maintained by industry in global assets by increasing $14 \%$ to $\$ 3.374$ trillion in 2020 . Similarly, Sukuks, the next-largest division in Islamic finance, raised by $16 \%$ in 2020 propelled by the Gulf Cooperation Council (GCC) as well as Southeast Asia (Alam and Ansari, 2020; Yesuf and Aassouli, 2020).

\section{Islamic Finance and Covid 19}

The Covid-19 pandemic and related lockdown have negatively impacted worldwide economic activities. As the pandemic expands and regulators-imposed lockdowns to reduce escalation, the impact of this epidemic has touched beyond the public health sector (Banna et al., 2021). The current pandemic negatively contributed to the real economy which created serious economic concerns and projected data from the Economic Intelligence Unit showing a devastating effect of the Covid-19 crisis on fiscal and monitory growth in most countries (Rabbani et al., 2020). Though the Covid-19 virus is an exogenous jolt to the economic and financial system, the Islamic financial services industry is not immune to such a crisis (Allaymoun and Hamid, 2020). The expected shortfall in performance of Islamic financial service business is not significantly distinct from the conventional business. However, data is evident that Shari'ah-compliant products and equities achieved noticeably healthier than conventional equities (Baber, 2020b).

\section{Sukuk: Islamic Capital Market}

The capital markets, an important resource of investment, are not exempt from the collision of Covid-19. With a burst of anticipated credit rating reductions, funds accessibility will be restricted to high-quality 
issuers, which will be expected to rise in more severity. Non-payments and reshuffles are very likely in the near time, although at a considerably greater cost of financing. With the help of the capital markets, established countries have declared asset acquisition programs that caused a huge movement in the debt and equity markets.

The Islamic capital markets are the other most substantial element of the Islamic finance sector, where Sukūk are the most important contributors (Rabbani and Khan, 2020). Figure 4 \& 5 describes the outstanding aggregate as sector-wise of Sukük as of 2020 (Hassan, Rabbani and Mohd. Ali, 2020). The substantial amount of the outstanding Sukük is condensed with financial institutions and sovereigns (Selim, 2020). The sovereign Sukūk market is less likely impacted by the Covid19 and in the case of Sukūk released by financial institutions, in the over five years, numerous Islamic banks increased resources utilizing Tier I and Tier II Sukūk to meet up the governing capital obligations (Nastiti and Kasri, 2019). Most of these issues have maturities near to perpetuity and do not pose a complete risk as such except there is a crisis in the ancillary market (Başarir, 2020; Dinc, 2020; Isa and Lee, 2020).

In GCC, the Islamic banking and financial institution with various retail and corporate products have remained to outperform conventional banking Figure $6 \& 7$. This is mirrored by progress seen in the overall credit books of the majority of the leading Islamic banks in the area by the size of the assets (Alam, Gupta and Zameni, 2019). The retail aim of Islamic banks in the GCC nations offers greater strength for their financing outlines and hence usually presents a substantial benefit over their conventional counterparts in terms of liquidity coverage ratio (LCR) (Gün, 2019). The banks in GCC, which are extra dependent on corporate deposits and institutional funding show lesser LCRs since the greater outflow rates that their grant base attracts (Afandi and Muta'ali, 2019). This let the Islamic banks continue strong and resilient despite the economic slump triggered by the pandemic in 2020 (Baber, 2020a). Besides, during last year, among the total financing assets, the share of Islamic financing assets soared (Yousaf, Suleman and Demirer, 2022). As expected by Moody this progress remained even during 2021 and amalgamations amongst Islamic and conventional banks in the GCC increased in assets (Kok and Filomeni, 2021). Inside the province, Islamic banks have surpassed conventional banks through all nations, excluding the UAE, in terms of asset volume growth between 2018 and 2019 (Jan, Lai and Tahir, 2021).

Amid weak performance by the greater part of the conventional financial organizations, particularly during the worldwide economic crisis, Islamic Banking organizations have remained strong internationally (El Saleh and Jurdi, 2021). The fundamental form of such banks, which call up for assetfinanced financial products, providing profit-equalization assets, and reserving more liquidity, support them in moments of market agony (Siti Fatihah et al., 2021). While the risk profiles of conventional and Islamic financial structures are different, Islamic banks demonstrate lesser risk rates on an average, as associated with conventional reserves. For Islamic banks, the greater the leveraging and greater the net profit margin, the greater the subsistence likelihood, while the similar is usually negative for conventional banks. Nevertheless, Islamic banking's severe dependence on cash investments and the use of products 
for security makes them comparatively more susceptible to high-level inflation and real financial activity (Billah, 2021).

The Shariah-compliant equity (Figure 8 \& 9) investment offers a safeguard against the sinking risk, as proved throughout the COVID-19 pandemic (Mehri et al., 2021). During March 2020, the S\&P Global 1200 fell by $23 \%$ y-o-y though S\&P Global 1200 Shariah was found to be recorded a drop of 17\% y-o-y. Between 2015 and 2020, the S\&P Global 1200 (conventional) raised at a compound annual growth rate (CAGR) of $9.5 \%$ in compared to S\&P Global 1200 Shariah growth rate of $13.6 \%$ CAGR in a similar phase (Standard \& Poor's, 2020). In absolute return, there was a $57.3 \%$ rose in conventional S\&P Global 1200 compared to S\&P Global 1200 Shariah is $88.9 \%$, which is an outperformance of $31.6 \%$ in this duration (Qudah et al., 2021). Except underperformance during 2016, the Shariah index has outperformed the conventional index between 2015 and 2016 (Bakar, Rosbi and Bakar, 2021).

The economic and social uncertainties due to the COVID-19 pandemic are headed to sporadic swings in equity markets worldwide during 2020 (Majeed and Zainab, 2021). The reports state a drop of 31.9\% in the S\&P Global 1200 YTD by March-end 2020, during this period the S\&P Global 1200 Shariah was down by $28.0 \%$, an outperformance of $3.9 \%$ (El Khamlichi et al., 2021). Despite the challenges and intense decline until March 2020, global equity markets ended the year on an optimistic note. At the end of 2020, S\&P Global 1200 rose by $66.1 \%$, meanwhile the S\&P Global 1200 Shariah was up by $70.2 \%$, outperformance of $4.0 \%$ compared to conventional. Figure 9 displays health care and technology that have added to the outperformance of Shariah-compliant indices (Lubza Nihar and Modekurti, 2021).

\section{Opportunities and challenges of adopting FinTech and Al in Arabian Islamic banking}

Most emerging financial technology companies in the Arab countries seek to expand the scope of cooperation and partnership with the banking sector, especially Islamic banks in the Arab region (Liu and Chang, 2021). Thus, the partnership that arises between the banking sector and the emerging companies in the field of financial technology, can have a positive impact on these banks by helping them to survive in the market and maintain their market share (B., A., and I., 2021; YAP, LAU and ISMAIL, 2021). This requires the Arab banking sector to be able to provide its customers with banking products and services that compete with those of traditional banks. Financial and digital technology, in addition to artificial intelligence, constitute great opportunities for the Arab banking sector to advance and keep pace with developments in the field of finance, especially Islamic finance around the world (Sherif, 2020). As for the risks that may result from the application of financial technology and artificial intelligence in banking operations, they can be divided into strategic risks, operational risks, financing risks, compliance risks, electronic risks, outsourcing risks, and liquidity risks (Mohd Noor et al., 2020).

Within this framework, artificial intelligence and financial technology will have a significant impact on restructuring banking operations to become invisible in the future, whereby the human element is 
completely dispensed within completing most of the financial transactions requested by customers (Rahman et al., 2020). However, this option will greatly contribute to the use of financial technology and artificial intelligence to improve the efficiency of banking operations and enhance the capabilities of employees without completely laying off them by providing smarter solutions to customers, ensuring the implementation of transactions as quickly and at the lowest possible cost (Islam and Ahmad, 2020). In addition to the important role of financial technology in managing banking operations, it may pose a major threat that must be taken into account and reassessed on an ongoing basis to ensure the safety and integrity of financial operations and the stability of the financial and banking sector in general (May 2020).

The intense competition witnessed by traditional financial institutions and financial technology companies in providing financial services has led to many banks seeking to introduce some changes in their business models. By expanding reliance on technology and investing in its infrastructure. For example, reports indicate that Gulf banks' reliance on modern technology carries many opportunities and challenges, on top of these opportunities, enhancing customer experience and facilitating banking operations (Khan and Azmat, 2020). As for the obstacles and restrictions, there are concerns related to the technological penetration of the internal information of these banks, which may cause severe damage to the systems of these banks, and despite these concerns, the overwhelming majority of executives in Gulf Cooperation Council banks are still embarking on developing various solutions., to overcome those obstacles, and most importantly, there is a tendency to enhance inter-bank cooperation at the international level, and in this regard, technological systems are the first way to achieve this (Zaremba et al., 2020).

\section{Conclusion}

The COVID-19 pandemic underlined the Islamic finance industry's vulnerability to exogenic threats, as it was subjected to the serious consequences of the pandemic in the same amount as its conventional counterpart. Islamic financial organizations devoted most of 2020 to surviving with the twin blows of adapting to the pandemic and previously low oil rates. Accordingly, the industry slowdown during the year after undergoing a $14.4 \%$ y-o-y increase in 2019. Total Islamic financial assets are projected to have touched US $\$ 2.9$ trillion by the end of 2020 , coordinating last year's totals. Thus, a quick and active reaction has now become essential to guarantee productivity, as well as stimulate improvement and development in commerce. The upswing in technology implementation, digital keys, decision making via data-driven mode, and data distribution throughout the banking, capital markets, finance, and microfinance fields, are expected to accelerate this improvement and strengthen the industry's whole resilience. For now, Islamic social finance instruments are expected to establish a more predominant position in the international market, along with exclusive Islamic investment products such as Sukuk, which be able to be leveraged as substitute financing means during the COVID-19 induced consequences and slowdown. 


\section{Abbreviation}

\begin{tabular}{|ll|}
\hline Fintech & Financial technology \\
\hline Al & Artificial Intelligence \\
\hline IoT & Internet of thinking \\
\hline GCC & Gulf Cooperation Council \\
\hline Sukuk & Islamic Bonds \\
\hline RegTech & Regulatory process \\
\hline
\end{tabular}

\section{Declarations}

\section{Declaration of Conflicting Interest}

The authors declared no potential conflicts of interest with respect to the research, authorship and/or publication of this article.

\section{Competing interests}

We are hereby declaring that there is "No Competing interests"

\section{Funding}

The authors received no financial support for the research, authorship and/or publication of this article.

\section{Availability of data and materials}

All data generated or analyzed during this study are included in this published article.

\section{Authors' contributions}

Author 1: Conceptualization, Investigation, Project administration.

Author 2: Software, Validation, Visualization and Statistical analysis, Methodology.

Author 3: Data curation, Formal analysis, original draft writing.

Author 4: Review and Editing, Supervision, Resources, investigation.

\section{Acknowledgements}

We hereby acknowledge all institutions provided data as open source and experts who shared their view.

\section{References}


1. Abdullah, A., Hassan, R., \& Kassim, S. (2020). 'A real asset management approach for Islamic investment in containerships', Journal of Islamic Accounting and Business Research. College of Economics and Management, Al Qasimia University, Sharjah, United Arab Emirates. Emerald Group Holdings Ltd, 11(1), 27-48. doi: 10.1108/JIABR-07-2017-0105

2. Adam, S. B., Al-Aidaros, A. M. H., Ishak, S. B., \& Journal of Social Sciences Research. (2018). 'The moderating effect of Islamic work ethics on the relationship between corporate governance and performance of Islamic financial institutions in Nigeria: A proposed framework',. Islamic Business School, Universiti Utara Malaysia, Sintok, Kedah, 06010, Malaysia: Academic Research Publishing Group, 2018(Special Issue 6), pp. 1041-1048. doi: 10.32861/jssr.spi6.1041.1048

3. Afandi, M. A., \& Muta'ali, A. (2019). 'Will traditional bank's customers switch to Fintech lending? A perspective of push-pull-mooring framework', in 11th International Conference on Information Management and Engineering, ICIME 2019. Department of Islamic and Middle East Studies, Universitas Indonesia, Jakarta, Indonesia: ICST, pp. 38-43. doi: 10.1145/3373744.3373752

4. Ahmad, W., Rais, S., \& Shaik, A. R. (2018). 'Modelling the directional spillovers from DJIM Index to conventional benchmarks: Different this time?', Quarterly Review of Economics and Finance. Department of Economic Sciences, Indian Institute of Technology Kanpur, Kanpur, UP 20801, India: Elsevier B.V., 67, pp. 14-27. doi: 10.1016/j.qref.2017.04.012

5. Alam, M., \& Ansari, V. A. (2020). 'Are Islamic indices a viable investment avenue? An empirical study of Islamic and conventional indices in India', International Journal of Islamic and Middle Eastern Finance and Management (13 vol., pp. 503-518). Aligarh, India: Emerald Group Holdings Ltd.. Department of Business Administration, Aligarh Muslim University,3doi: 10.1108/IMEFM-03-20190121

6. Alam, N., Gupta, L., \& Zameni, A. (2019). Fintech and Islamic finance: Digitalization, development and disruption. Fintech and Islamic Finance: Digitalization, Development and Disruption. Henley Business School, University of Reading Malaysia, Iskandar Puteri. Johor, Malaysia: Springer International Publishing. doi: 10.1007/978-3-030-24666-2

7. Ali, H., Ahmad, I., \& Kamaruddin, B. H. (2020). 'Efficiency performance of smes firms: A case study of islamic financing guarantee scheme of credit guarantee corporation', Malaysian Journal of Consumer and Family Economics. Faculty of Business and Management, Universiti Teknologi MARA Puncak AlamSelangor, Malaysia: Malaysian Consumer and Family Economics Association, 24(S2), pp. 120-134. Available at: https://www.scopus.com/inward/record.uri?eid=2-s2.085094199040\&partnerID $=40 \& m d 5=d c 630 d 9 f c 4 e c 36051821$ a66ce6964737

8. Allaymoun, M. H., \& Hamid, O. A. H. (2020). 'Proposed Mobile Application for Islamic Fintech E-Salam System an Approach to the Financial Inclusion', in 2020 International Conference on Data Analytics for Business and Industry: Way Towards a Sustainable Economy, ICDABI 2020. Ama International University-Bahrain, Manama, Bahrain: Institute of Electrical and Electronics Engineers Inc. doi: 10.1109/ICDABI51230.2020.9325698

9. Alziyadat, N., \& Ahmed, H. (2019). 'Ethical decision-making in Islamic financial institutions in light of Maqasid Al-Sharia: A conceptual framework'. Thunderbird International Business Review. Centre for 
Responsible Citizenship and Sustainability, School of Business and Governance, Murdoch University (61 vol., pp. 707-718). Perth, WA, Australia: Wiley-Liss Inc.. 5doi: 10.1002/tie.22025

10. Aziz, Y., et al. (2020). 'Islamic practices and small and medium enterprises performance: Is corporate social responsibility a missing link?', Journal of Public Affairs. Department of Shariah and Management, Academy of Islamic Studies, University of Malaya, Kuala Lumpur, Malaysia: John Wiley and Sons Ltd. doi: 10.1002/pa.2314

11. B., A., A., H. and I., E. (eds) 'International Conference on Business and Technology, ICBT 2020' (2021). International Conference on Business and Technology, ICBT 2020. Springer Science and Business Media Deutschland GmbH. Available at: https://www.scopus.com/inward/record.uri?eid=2-s2.085104422369\&partnerID =40\&md5=c9c030f00f9a1c5ff9b632adc3ff8972

12. Baber, H. (2020a). 'Financial inclusion and FinTech: A comparative study of countries following Islamic finance and conventional finance', Qualitative Research in Financial Markets. Endicott College of International Studies, Woosong University, Daejeon, South Korea: Emerald Group Holdings Ltd., 12(1), pp. 24-42. doi: 10.1108/QRFM-12-2018-0131

13. Baber, H. (2020b). 'FinTech, Crowdfunding and Customer Retention in Islamic Banks', Vision. Endicott College of International Studies, Woosong University, Jayang-Dong, Dong-gu (24 vol., pp. 260-268). Daejeon, South Korea: Sage Publications India Pvt. Ltd. 3doi: 10.1177/0972262919869765

14. Bakar, N. A., Rosbi, S., \& Bakar, A. A. (2021). 'Evaluation of Students Performance using Fuzzy Set Theory in Online Learning of Islamic Finance Course', International Journal of Interactive Mobile Technologies. Universiti Utara Malaysia, Kedah, Malaysia: International Association of Online Engineering, 15(7), pp. 202-209. Available at: https://www.scopus.com/inward/record.uri?eid=2s2.0-85112653031\&partnerID=40\&md5=9313320b8daca4f6d7762991b5aa18f2

15. Banna, H., et al. (2021). 'Islamic banking stability amidst the COVID-19 pandemic: the role of digital financial inclusion', International Journal of Islamic and Middle Eastern Finance and Management. Ungku Aziz Centre for Development Studies, Universiti Malaya, Faculty of Economics and Administration, Kuala Lumpur, Malaysia: Emerald Group Holdings Ltd. doi: 10.1108/IMEFM-08-20200389

16. Başarir, C. (2020). Current issues in finance, economy and politics, Current Issues in Finance, Economy and Politics. Bandirma Onyedi Eylul University, International Trade and Logistics Department, Turkey: Peter Lang AG. doi: 10.3726/b16226

17. Billah, M. M. (2021). Benchmarking Islamic Finance: A Framework for Evaluating Financial Products and Services, Benchmarking Islamic Finance: A Framework for Evaluating Financial Products and Services. Islamic Economics Institute, King Abdul Aziz University, Jeddah, Saudi Arabia: Taylor and Francis. doi: 10.4324/9781003089988

18. Boudt, K., Raza, M. W., \& Wauters, M. (2019). 'Evaluating the Shariah-compliance of equity portfolios: The weighting method matters', International Review of Financial Analysis. Solvay Business School, Vrije Universiteit Brussel (63 vol., pp. 406-417). Belgium: Elsevier Inc.. doi:

10.1016/j.irfa.2017.12.003

Page 19/35 
19. Buallay, A. M., et al. (2020). 'Evaluating ESG disclosures of Islamic banks: Evidence from the Organization of Islamic Cooperation Members', International Journal of Innovation and Sustainable Development. Brunel Business School, Brunel University, London, United Kingdom: Inderscience Publishers, 14(3), pp. 266-287. doi: 10.1504/IJISD.2020.108045

20. Causevic, E. (2018). 'The Relationship Between the Performance of Islamic and Conventional Banks', Lecture Notes in Networks and Systems. Sarajevo School of Science and Technology, Ilidža, Bosnia and Herzegovina (pp. 256-264). Springer. doi: 10.1007/978-3-319-71321-2_23

21. Crossmark global (2020). GLOBAL EQUITY INCOME Snapshot, Encyclopedia of Corporate Social Responsibility. doi: 10.1007/978-3-642-28036-8_101181

22. Dharani, M., Hassan, M. K., \& Paltrinieri, A. (2019). 'Faith-based norms and portfolio performance: Evidence from India', Global Finance Journal. Department of Finance, ICFAI Business School (IBS), (A Constituent of IFHE, Deemed to be University), Hyderabad, Telangana 501203, India (41 vol., pp. 7989). Elsevier B.V.. doi: 10.1016/j.gfj.2019.02.001

23. Dinc, Y. (2020). 'Product development in Islamic finance and banking in secular economies', Journal of Islamic Accounting and Business Research. Department of Islamic Economics and Finance, Istanbul Sabahattin Zaim Universitesi, Istanbul, Turkey: Emerald Group Holdings Ltd., 11(9), pp. 1665-1676. doi: 10.1108/JIABR-06-2019-0106

24. Elgadi, E. M., \& Yu, E. P. Y. (2018). 'The profitability of Islamic banking in Sudan', International Journal of Management Practice. University of East London, 1 Salway PI, London, E15 1NF, United Kingdom: Inderscience Publishers, 11(3), pp. 233-258. doi: 10.1504/IJMP.2018.092859

25. Elhaj, M. A., Muhamed, N. A., \& Ramli, N. M. (2018). 'The effects of board attributes on Sukuk rating', International Journal of Islamic and Middle Eastern Finance and Management. Faculty of Economics and Muamalat, Universiti Sains Islam Malaysia (11 vol., pp. 312-330). Nilai, Malaysia: Emerald Group Holdings Ltd.. 2doi: 10.1108/IMEFM-03-2017-0057

26. Ghosh, S. (2018). 'Governance reforms and performance of MENA banks: Are disclosures effective?', Global Finance Journal. Centre for Advanced Financial Research and Learning, Fort, Mumbai, Maharashtra 400001, India: Elsevier B.V., 36, pp. 78-95. doi: 10.1016/j.gfj.2018.01.002

27. Gözübüyük, R., Kock, C. J., \& Ünal, M. (2020). 'Who appropriates centrality rents? The role of institutions in regulating social networks in the global Islamic finance industry'. Journal of International Business Studies. Sabanci School of Management, Sabanci University, Universite Caddesi 27, Tuzla, Istanbul 34956 (51 vol., pp. 764-787). Turkey: Palgrave Macmillan Ltd.. 5doi: $10.1057 / \mathrm{s} 41267-018-0202-4$

28. Gün, M. (2019). 'The path to fintech development research on islamic finance in Turkey', in Impact of Financial Technology (FinTech) on Islamic Finance and Financial Stability. Recep Tayyip Erdogan University, Turkey: IGI Global, pp. 65-96. doi: 10.4018/978-1-7998-0039-2.ch005

29. Hanif, M. (2018). 'Sharī ah-compliance ratings of the Islamic financial services industry: a quantitative approach', ISRA International Journal of Islamic Finance. College of Business 
Administration, Ajman University of Science and Technology, Ajman, United Arab Emirates: Emerald Group Holdings Ltd., 10(2), pp. 162-184. doi: 10.1108/IJIF-10-2017-0038

30. Hasim, H. F. A., Ariffin, N. M., \& Zakaria, M. Z. (2019). 'Strategic management system framework in Shariah compliant hotel in Malaysia', International Journal of Advanced Trends in Computer Science and Engineering. Faculty of Computer \& Mathematic Sciences, University Technology Mara, Malaysia: World Academy of Research in Science and Engineering, 8(1.6 Special Issue), pp. 416423. doi: $10.30534 /$ ijatcse/2019/6081.62019

31. Hassan, M. K., et al. (2020). 'A review of Islamic stock market, growth and real-estate finance literature', International Journal of Emerging Markets. Department of Economics and Finance, University of New Orleans, New Orleans, LA, United States: Emerald Group Holdings Ltd., 16(7), pp. 1259-1290. doi: 10.1108/IJOEM-11-2019-1001

32. Hassan, M. K., Rabbani, M. R., \& Mohd. Ali, M. A. (2020). 'Challenges for the islamic finance and banking in post COVID era and the role of Fintech', Journal of Economic Cooperation and Development. Department of Economics and Finance, University of New Orleans, New Orleans, LA, United States: Statistical Economic and Social Research and, 41(3), pp. 93-116. Available at: https://www.scopus.com/inward/record.uri?eid=2-s2.085100874267\&partnerID=40\&md5=758d028b01e4ca948f4fbad22c0ecb14

33. Ho, C. S. F., Mohd-Raff, N. E. N., \& Teknologi, M. A. R. A. (2019). Shah Alam, Malaysia:Emerald Group Holdings Ltd., 12(2),236-253. doi: 10.1108/IMEFM-08-2017-0202.

34. ICD (2020). 'Progressing Through Development', ICD-REFINITIV Islamic Finance Development Report 2020

35. IFD (2020). 'Islamic Finance Development Report 2020: Progressing Through Development', Islamic Finance Development Report, pp. 1-54

36. Isa, M., \& Lee, S. P. (2020). 'Does the Shariah committee influence risk-taking and performance of Islamic banks in Malaysia?', Journal of Islamic Accounting and Business Research. Department of Finance and Banking, Faculty of Business and Accountancy, University of Malaya (11 vol., pp. 17391755). Kuala Lumpur, Malaysia: Emerald Group Holdings Ltd.. 9doi: 10.1108/JIABR-12-2018-0207

37. Islam, R., Ahmad, R., \& ISRA International Journal of Islamic Finance. (2020). 'Muḍārabah and mushārakah as micro-equity finance: perception of Selangor's disadvantaged women entrepreneurs',. Albukhary International University, Alor Setar, Malaysia: Emerald Group Holdings Ltd., 12(2), pp. 217237. doi: 10.1108/IJIF-04-2018-0041

38. Jan, A. A., Lai, F. W., \& Tahir, M. (2021). 'Developing an Islamic Corporate Governance framework to examine sustainability performance in Islamic Banks and Financial Institutions', Journal of Cleaner Production. Department of Management and Humanities, Universiti Teknologi PETRONAS, Seri Iskandar, Perak 32610, Malaysia (p. 315). Elsevier Ltd. doi: 10.1016/j.jclepro.2021.128099

39. Javaid, S., \& Al-Malkawi, H. A. N. (2018). 'Corporate social responsibility and financial performance in Saudi Arabia: Evidence from Zakat contribution', Managerial Finance. Faculty of Economics and 
Administration, King Abdulaziz University, Jeddah, Saudi Arabia (44 vol., pp. 648-664). Emerald Group Holdings Ltd.. 6doi: 10.1108/MF-12-2016-0366

40. Kabir Hassan, M., Rashid, M., \& Aliyu, S. (2019). Islamic corporate finance, Islamic Corporate Finance. University of New OrleansLA, United States: Taylor and Francis. doi: 10.4324/9781351061506

41. Kartiwi, M., et al. (2018). 'Sukuk rating prediction using voting ensemble strategy', International Journal of Electrical and Computer Engineering. Departement of Electrical Engineering, International Islamic University Malaysia, Malaysia: Institute of Advanced Engineering and Science, 8(1), pp. 299303. doi: 10.11591/ijece.v8i1.pp299-303

42. Khairulanuwar, A. J., \& Chuweni, N. N. (2020). 'The significance and performance analysis of Malaysian real estate investment trusts', International Journal of Law and Management. Department of Estate Management, Faculty of Architecture, Planning and Surveying. In U. Teknologi MARA (Ed.), Perak Branch, Seri Iskandar Campus (63 vol., pp. 417-430). Seri Iskandar, Malaysia: Emerald Group Holdings Ltd.. 4doi: 10.1108/IJLMA-01-2020-0022

43. El Khamlichi, A., et al. (2021). 'Do Islamic stock indices perform better than their conventional counterparts?', International Journal of Business Performance Management. LERSEM, ENCG, Chouaib Doukkali University, El Jadida, Morocco: Inderscience Publishers, 22(2-3), pp. 236-256. doi: 10.1504/IJBPM.2021.116417

44. Khan, M. N., et al. (2018). 'Efficiency measurement of islamic and conventional banks in saudi arabia: An empirical and comparative analysis', Al-Shajarah. International Islamic University Malaysia, 2018(Special Issue), pp. 111-134. Available at:

https://www.scopus.com/inward/record.uri?eid=2-s2.085059507052\&partnerlD=40\&md5=731c7b7018a55c240f35657770baeb58

45. Khan, S., \& Azmat, S. (2020). 'Debt externality in equity markets: Leveraged portfolios and Islamic indices', International Review of Economics and Finance. Suleman Dawood School of Business, Lahore University of Management Sciences, D.H.A, Lahore, 54792, Pakistan (69 vol., pp. 152-177). Elsevier Inc.. doi: 10.1016/j.iref.2020.05.004

46. Khan, S., \& Rabbani, M. R. (2020). 'Chatbot as islamic finance expert (CalFE): When finance meets artificial intelligence', in 4th International Symposium on Computer Science and Intelligent Control, ISCSIC 2020. Department of Information Technology, University College of Bahrain, Bahrain:

Association for Computing Machinery. doi: 10.1145/3440084.3441213

47. Klein, P. O., Weill, L., \& Godlewski, C. J. (2018). 'How sukuk shapes firm performance', World Economy. University of Strasbourg (41 vol., pp. 699-722). Strasbourg, France: Blackwell Publishing Ltd. 3doi: $10.1111 /$ twec. 12509

48. Kok, S. K., \& Filomeni, S. (2021). 'The holding behavior of Shariah financial assets within the global Islamic financial sector: A macroeconomic and firm-based model', Global Finance Journal. University of Essex, Essex Business School, Finance Group, Wivenhoe Park, Colchester, UK CO4 3SQ, United Kingdom: Elsevier B.V., 50. doi: 10.1016/j.gfj.2020.100557 
49. Kuran, T. (2018). 'Islam and economic performance: Historical and contemporary links', Journal of Economic Literature. Department of Economics and Political Science, Duke University, United States: American Economic Association, 56, pp. 1292-1359. doi: 10.1257/jel.20171243

50. De La, O., González, M., Jareño, F., \& El Haddouti, C. (2018). 'The islamic financial industry: Performance of Islamic vs. conventional sector portfolios', 2018 Mathematical and Statistical Methods for Actuarial Sciences and Finance, MAF 2018. Edited by C. M. et al. University of CastillaLa Mancha, Albacete, Spain: Springer International Publishing AG, pp. 407-411. doi: 10.1007/978-3319-89824-7_73

51. Laallam, A., et al. (2020). 'Intellectual capital in non-profit organisations: lessons learnt for waqf institutions', ISRA International Journal of Islamic Finance. Institute of Islamic Banking and Finance, International Islamic University Malaysia, Kuala Lumpur, Malaysia: Emerald Group Holdings Ltd., 12(1), pp. 27-48. doi: 10.1108/IJIF-10-2018-0111

52. Labuan, I. B. F. C. (2020). IIFM Annual Sukuk Report

53. Liu, W. H., \& Chang, J. R. (2021). 'Revisiting and refining the comparison of conventional and islamic markets' performance'. Applied Economics. School of Business, Southern University of Science and Technology, Shenzhen, Guangdong (53 vol., pp. 4371-4385). China: Routledge. 38doi: 10.1080/00036846.2021.1900533

54. Lubza Nihar, K., \& Modekurti, K. R. V. S. (2021). 'On being Sharī ah compliant in equity investments: impact of investment horizon andmarket volatility', Journal of Islamic Accounting and Business Research. Department of Finance, GITAM Institute of Management, Gandhi Institute of Technology and Management (12 vol., pp. 680-706). Visakhapatnam, India: Emerald Group Holdings Ltd.. 5doi: 10.1108/JIABR-05-2020-0142

55. Majeed, M. T., Zainab, A., \& University, Q. I. A. (2021). Islamabad, Pakistan:Emerald Group Holdings Ltd., 13(3),331-346. doi: 10.1108/IJIF-08-2018-0093.

56. Masih, M., Kamil, N. K. M., Bacha, O. I. 'Issues in Islamic Equities: A Literature Survey', Emerging Markets Finance and Trade. INCEIF, \& Lorong Universiti, A. (2018). Kuala Lumpur, Malaysia: Routledge, 54(1), pp. 1-26. doi: 10.1080/1540496X.2016.1234370

57. May, S. (2020). 'Islamic Charitable Giving in the UK: A "Radical" Economic Alternative?', New Political Economy. School of Social Sciences, University of Aberdeen (25 vol., pp. 913-925). Aberdeen, United Kingdom: Routledge. 6doi: 10.1080/13563467.2019.1664445

58. Mehri, M., et al. (2021). 'Do determinants of fees differ between Islamic and conventional funds?'. International Journal of Finance and Economics. Zitouna Bank (26 vol., pp. 3599-3623). Tunis, Tunisia: John Wiley and Sons Ltd. 3doi: 10.1002/ijfe.1978

59. Mohammed, H. Y., \& Abu Rumman, A. A. (2018). 'The impact of macroeconomic indicators on Qatar stock exchange: A comparative study between Qatar exchange index and Al Rayyan Islamic index $†$ †'. Journal of Transnational Management. College of Islamic Studies, Hamad Bin Khalifa University (23 vol., pp. 154-177). Doha, Qatar: Routledge. 4doi: 10.1080/15475778.2018.1512342 
60. Mohd-Rashid, R., \& Tajuddin, A. H. (2019). 'Sukuk: Introduction and global performance', in Islamic Corporate Finance. School of Economics, Finance and Banking, Universiti Utara Malaysia, Kedah, Malaysia: Taylor and Francis, pp. 123-135. doi: 10.4324/9781351061506-6

61. Mohd Ali, N. A., Shafii, Z., \& Shahimi, S. (2020). 'Competency model for Shari'ah auditors in Islamic banks'. Journal of Islamic Accounting and Business Research. Faculty of Accountancy, MARA University of Technology Melaka, Alor Gajah (11 vol., pp. 377-399). Malaysia: Emerald Group Holdings Ltd.. 2doi: 10.1108/JIABR-09-2016-0106

62. Mohd Noor, N. H. H., et al. (2020). 'The Impact of the Bank Regulation and Supervision on the Efficiency of Islamic Banks', Journal of Asian Finance, Economics and Business. Faculty of Business and Management, UiTM Kelantan, Malaysia: Korea Distribution Science Association (KODISA), 7(11), pp. 747-757. doi: 10.13106/jafeb.2020.vol7.no11.747

63. Muhammad, R., Suluki, A., \& Nugraheni, P. (2020). 'Internal factors and non-performing financing in Indonesian Islamic rural banks', Cogent Business and Management. Department of Accounting, Universitas Islam Indonesia, Yogyakarta, Indonesia: Cogent OA, 7(1). doi:

$10.1080 / 23311975.2020 .1823583$

64. Murdayanti, Y., \& Puruwita, D. (2018). 'The strategic formulation in islamic education institutions', in K.S., S. (ed.) 32nd International Business Information Management Association Conference, IBIMA 2018. Universitas Negeri Jakarta, Jakarta, Indonesia: International Business Information Management Association, IBIMA, pp. 6907-6914. Available at: https://www.scopus.com/inward/record.uri?eid=2-s2.085063048319\&partnerID=40\&md5=bb7d609d0235bb5ed2d0a1c9258621eb

65. Nastiti, N. D., \& Kasri, R. A. (2019). 'The role of banking regulation in the development of Islamic banking financing in Indonesia', International Journal of Islamic and Middle Eastern Finance and Management (,12Emerald Group Holdings Ltd., 12 vol., pp. 643-662). Depok, Indonesia: Department of Economics, University of Indonesia. 5doi: 10.1108/IMEFM-10-2018-0365

66. Noor, N. F. M. (2018). 'Determinants of islamic bank's leverage ratio in malaysia', Management and Accounting Review. University of Selangor, Malaysia: Universiti Teknologi Mara, 17(1), pp. 109-122. doi: 10.24191/mar.v17i1.761

67. Othman, A., \& Tahir, P. R. (2019). 'A conceptual framework on moderating effect of frontline service employees on factors leading to strong branding of small Islamic banks', International Journal of Innovation, Creativity and Change. Faculty of Business and Management, DRB-Hicom University of Automotive Malaysia (DRB-HICOM U), Malaysia: Primrose Hall Publishing Group, 7(3), pp. 173-185. Available at: https://www.scopus.com/inward/record.uri?eid=2-s2.085076980708\&partnerlD =40\&md5=bd92875f201df9014a09fbb6dc99e0f3

68. El Ouadghiri, I., \& Peillex, J. (2018). 'Public attention to "Islamic terrorism" and stock market returns'. Journal of Comparative Economics. Léonard de Vinci Pôle Universitaire, Research Center, Paris La Défense, France \& EconomiX-CNRS, University of Paris Nanterre (46 vol., pp. 936-946). France: Academic Press Inc.. 4doi: 10.1016/j.jce.2018.07.014 
69. Puruwita, D., \& Murdayanti, Y. (2018). 'Measuring financial management in islamic educational institutions in Indonesia', in K.S., S. (ed.) 32nd International Business Information Management Association Conference, IBIMA 2018. Universitas Negeri Jakarta, Jakarta, Indonesia: International Business Information Management Association, IBIMA, pp. 7120-7130. Available at: https://www.scopus.com/inward/record.uri?eid=2-s2.085063034141\&partnerID=40\&md5=94bea501ca592d462c5870709b2a0ec6

70. Qudah, H. A., et al. (2021). 'Liquidity risk measurement study case (Jordan islamic banks)', International Journal of Entrepreneurship. Al-Balqa Applied University, Jordan: Allied Business Academies, 25(8), pp. 1-9. Available at: https://www.scopus.com/inward/record.uri?eid=2-s2.085114298336\&partnerID=40\&md5=154b07b4b87830fda27a5dbe538fd019

71. Rabbani, M. R., et al. (2020). 'Embracing of Fintech in Islamic Finance in the post COVID era', in 2020 International Conference on Decision Aid Sciences and Application, DASA 2020. Kingdom University, Finance and Accounting Department, Riffa, Bahrain: Institute of Electrical and Electronics Engineers Inc., pp. 1230-1234. doi: 10.1109/DASA51403.2020.9317196

72. Rabbani, M. R., \& Khan, S. (2020). 'Agility and fintech is the future of islamic finance: a study from islamic banks in bahrain', International Journal of Scientific and Technology Research. Department of Finance and Accounting, College of Business Administration, Kingdom University, Bahrain: International Journal of Scientific and Technology Research, 9(3), pp. 6955-6957. Available at: https://www.scopus.com/inward/record.uri?eid=2-s2.085082874111\&partnerID=40\&md5=86b57f4db56f71626954811bbf5517c3

73. Rahman, M., et al. (2020). 'Socially responsible investment sukuk (Islamic bond) development in Malaysia', Qualitative Research in Financial Markets. Faculty of Business and Accountancy, University of Malaya, Kuala Lumpur, Malaysia: Emerald Group Holdings Ltd., 12(4), pp. 599-619. doi: 10.1108/QRFM-09-2019-0117

74. Ramli, N. A., Marzuki, A., \& Nazri, M. A. (2020). 'Mediation effects of firm leverage from the perspective of Malaysian shariah compliant companies-A partial least square structural equation modelling approach (PLS-SEM)', Research in World Economy. Faculty of Economics and Muamalat, University Sains Islam Malaysia, Bandar Baru Nilai (11 vol., pp. 67-79). Malaysia: Sciedu Press. 3doi: 10.5430/rwe.v11n3p67

75. Razak, M. I. A., et al. (2021). 'Fintech in Malaysia: An appraisal to the need of shariah-compliant regulation', Pertanika Journal of Social Sciences and Humanities. Faculty of Law, Multimedia University (MMU), Melaka, 75450, Malaysia: Universiti Putra Malaysia, 28(4), pp. 3223-3233. doi: 10.47836/PJSSH.28.4.40

76. Rehman, Z. U., et al. (2020). ‘Do corporate social responsibility disclosures improve financial performance? A perspective of the Islamic banking industry in Pakistan', Sustainability (Switzerland). Department of Management Sciences, City University of Science and IT, Peshawar, 25000, Pakistan: MDPI, 12(8). doi: 10.3390/SU12083302

77. Rosman, R., Haron, R., \& Othman, N. B. M. (2019). 'The impact of zakĀt contribution on the financial performance of islamic banks in malaysia', Al-Shajarah. IIUM, Institute of Islamic Banking and 
Finance (IliBF), Malaysia: International Islamic University Malaysia, 2019(Special Issue IslamicBankingandFinance2019), pp. 1-21. Available at:

https://www.scopus.com/inward/record.uri?eid=2-s2.0-

85078250523\&partnerID=40\&md5=aac3746314ee05b76954d4561925d2e2

78. El Saleh, A. I., \& Jurdi, D. J. (2021). 'Stock performance under alternative Shariah screening methods: Evidence from Australia', Accounting and Finance. Department of Economics, Finance and Marketing, La Trobe Business School, La Trobe University (61 vol., pp. 4339-4388). Melbourne, VIC, Australia: John Wiley and Sons Inc. 3doi: 10.1111/acfi.12735

79. Selim, M. (2020). 'The effects of eliminating Riba in foreign currency transactions by introducing global FinTech network', International Journal of Islamic and Middle Eastern Finance and Management. Department of Economics and Finance, University of Bahrain (14 vol., pp. 506-523). Sakheer, Bahrain: Emerald Group Holdings Ltd.. 3doi: 10.1108/IMEFM-01-2020-0035

80. Shabbir, M. S., et al. (2020). 'A study on the integration of islamic social finance through accounting and auditing organization for Islamic financial institutions (AAOIFI)', International Journal of Advanced Science and Technology. University of Lahore, Pakistan: Science and Engineering Research Support Society, 29(7 Special Issue), pp. 2069-2082. Available at: https://www.scopus.com/inward/record.uri?eid=2-s2.085084424977\&partnerID =40\&md5=635ce24dfd90017d5d1ba7463fb3f80e

81. Shaik Mohammed, W., \& Waheed, K. (2019). 'Interest-free microfinance in India: A case study of Sanghamam multistate cooperative credit society', Journal of Islamic Accounting and Business Research. Department of Management Studies, B S Abdur Rahman Crescent Institute of Science and Technology (10 vol., pp. 695-709). Chennai, India: Emerald Group Publishing Ltd.. 5doi:

10.1108/JIABR-11-2017-0176

82. Shaikh, O. (2020). 'On the relevance of higher-moments for portfolio-management within Islamic finance', International Journal of Islamic and Middle Eastern Finance and Management. School of Economics, University of Kent, Canterbury, United Kingdom: Emerald Group Holdings Ltd., 13(3), pp. 533-552. doi: 10.1108/IMEFM-11-2018-0388

83. Shaikh, S. A., et al. (2019). 'Overview of progress in Islamic commercial and social finance in Pakistan', in The Growth of Islamic Finance and Banking: Innovation, Governance and Risk Mitigation. School of Economics, National University of Malaysia, Selangor, Malaysia: Taylor and Francis, pp. 187-205. Available at: https://www.scopus.com/inward/record.uri?eid=2-s2.085116531598\&partnerID=40\&md5=d7c1c4f83267ac0069f8643bb68de5fb

84. Sherif, M. (2020). 'The impact of Coronavirus (COVID-19) outbreak on faith-based investments: An original analysis', Journal of Behavioral and Experimental Finance. Edinburgh Business School, Heriot-Watt University, Edinburgh, United Kingdom: Elsevier B.V., 28. doi: 10.1016/j.jbef.2020.100403

85. Siti-Nabiha, A. K., \& Norfarah, N. (2020). 'Performance of Islamic Microfinance Institutions: Accounting for Well-Being', Global Journal Al-Thaqafah. Graduate School of Business, Universiti Sains Malaysia, Minden, Penang, 11800, Malaysia: Kolej University Islam Sultan Azlan Shah, 10(2), 
pp. 38-46. Available at: https://www.scopus.com/inward/record.uri?eid=2-s2.0-

85101283190\&partnerID=40\&md5=29d9eb4c31ad06a85881 f80220a79c6e

86. Siti Fatihah, C. O., et al. (2021). 'The effect of aggregating bootstrap on the accuracy of neural network system for islamic investment prediction', Universal Journal of Accounting and Finance. Department of Mathematics, Faculty of Science and Mathematics, Universiti Pendidikan Sultan Idris, Perak, 35900, Malaysia. Horizon Research Publishing, 9(4), 604-612. doi:

10.13189/ujaf.2021.090408

87. Standard \& Poor's (2020). S \& P Global 1200 Methodology. Available at: http://us.spindices.com/indices/equity/sp-global-1200

88. Syachfuddin, L. A., \& Rosyidi, S. (2020). 'The effect of macroeconomic factors and market share on the sharia banking industry in Indonesia', International Journal of Innovation, Creativity and Change. Departemen Ekonomi Islam, Universitas Airlangga Surabaya60286, Indonesia: Primrose Hall Publishing Group, 11(9), pp. 210-218. Available at: https://www.scopus.com/inward/record.uri? eid $=2-s 2.0-85082195300 \&$ partnerlD $=40 \&$ md5=5c48d9c4df1b7327979caaae3b597ec6

89. Tarique, K. M., et al. (2020). 'Constructing a Maqasid (objective) based performance measurement index for Islamic banks', International Journal of the Analytic Hierarchy Process. University of Liberal Arts, Dhaka, Bangladesh: Creative Decisions Foundation, 12(2), pp. 328-354. doi:

10.13033/ijahp.v12i2.770

90. 'Economic, industry and corporate trends A report from the Economist Intelligence Unit', Intelligence, p. 97. Available at: file:The Economist Intelligence Unit, \& //C:/Users (2020). /matte/AppData/Local/Mendeley Ltd./Mendeley Desktop/Downloaded/Unit, Systems - Unknown Economic, industry and corporate trends A report from the Economist Intelligence Unit.pdf

91. Utomo, S. B., et al. (2020). 'Promoting Islamic financial ecosystem to improve halal industry performance in Indonesia: a demand and supply analysis'. Journal of Islamic Marketing. Department of Research in Financial Services Sector, Financial Services Authority of Indonesia, Central Jakarta (12 vol., pp. 992-1011). Indonesia: Emerald Group Holdings Ltd.. 5doi: 10.1108/JIMA-12-2019-0259

92. Wasiaturrahma, et al. (2020). 'Financial performance of rural banks in Indonesia: A two-stage DEA approach', Heliyon. Department of Economics (6 vol.). Universitas Airlangga, Indonesia: Elsevier Ltd. 7doi: 10.1016/j.heliyon.2020.e04390

93. Wediawati, B., University, et al. (2018). Indonesia: Allied Business Academies, 17(3). Available at: https://www.scopus.com/inward/record.uri?eid=2-s2.085068455513\&partnerID=40\&md5=0df56389149f59951792824ba25792e7

94. YAP, K. L., LAU, W.-Y. and, \& ISMAIL, I. (2021). 'A Comparative Study between Islamic and Conventional Exchange-Traded Funds: Evidence from Global Market Indices', Journal of Asian Finance, Economics and Business. Department of Finance and Banking, Faculty of Business and Accountancy, University of Malaya, Malaysia: Korea Distribution Science Association (KODISA), 8(2), pp. 725-735. doi: 10.13106/jafeb.2021.vol8.no2.0725 
95. Yesuf, A. J., \& Aassouli, D. (2020). 'Exploring synergies and performance evaluation between Islamic funds and socially responsible investment (SRIs). light of the Sustainable Development Goals (SDGs)', Heliyon. College of Islamic Studies, Hamad Bin Khalifa University, Education City (6 vol.). AlRayyan, Qatar: Elsevier Ltd. 8doi: 10.1016/j.heliyon.2020.e04562

96. Yousaf, I., Suleman, M. T., \& Demirer, R. (2022). 'Green investments: A luxury good or a financial necessity?', Energy Economics. Department of Business Studies, Namal University, Mianwali, Pakistan: Elsevier B.V., 105. doi: 10.1016/j.eneco.2021.105745

97. Zaki, l., et al. (2019). 'Business network strategy in islamic micro finance institution of islamic boarding school', Humanities and Social Sciences Reviews. Lecturer of Faculty of Economy and Business, Universitas Airlangga, Indonesia: Gyandhara International Academic Publications, 7(4), pp. 276-279. doi: 10.18510/hssr.2019.7435

98. Zaremba, A., et al. (2020). 'Dissecting anomalies in Islamic stocks: Integrated or segmented pricing?', Pacific Basin Finance Journal. Poznan University of Economics and Business, Poland: Elsevier B.V., 62. doi: 10.1016/j.pacfin.2018.05.006

99. Anagnostopoulos, I. (2018). " Fintech and regtech: Impact on regulators and banks. Journal of Economics and Business, 100, 7-25

100. Karim, S., Akhtar, M. U., Tashfeen, R., Rabbani, M. R., Rahman, A., A. A. and, \& AlAbbas (2021). a. "Sustainable banking regulations pre and during coronavirus outbreak: the moderating role of financial stability, Economic Research-Ekonomska Istraživanja, pp 1 - 19

101. Karim, S., Akhtar, M. U., Tashfeen, R., Rabbani, M. R., Abdul Rahman, A. A. and AlAbbas, a. (2021) "Sustainable banking regulations pre and during coronavirus outbreak: the moderating role of financial stability, Economic Research-Ekonomska Istraživanja, pp 1 - 19.

\section{Figures}




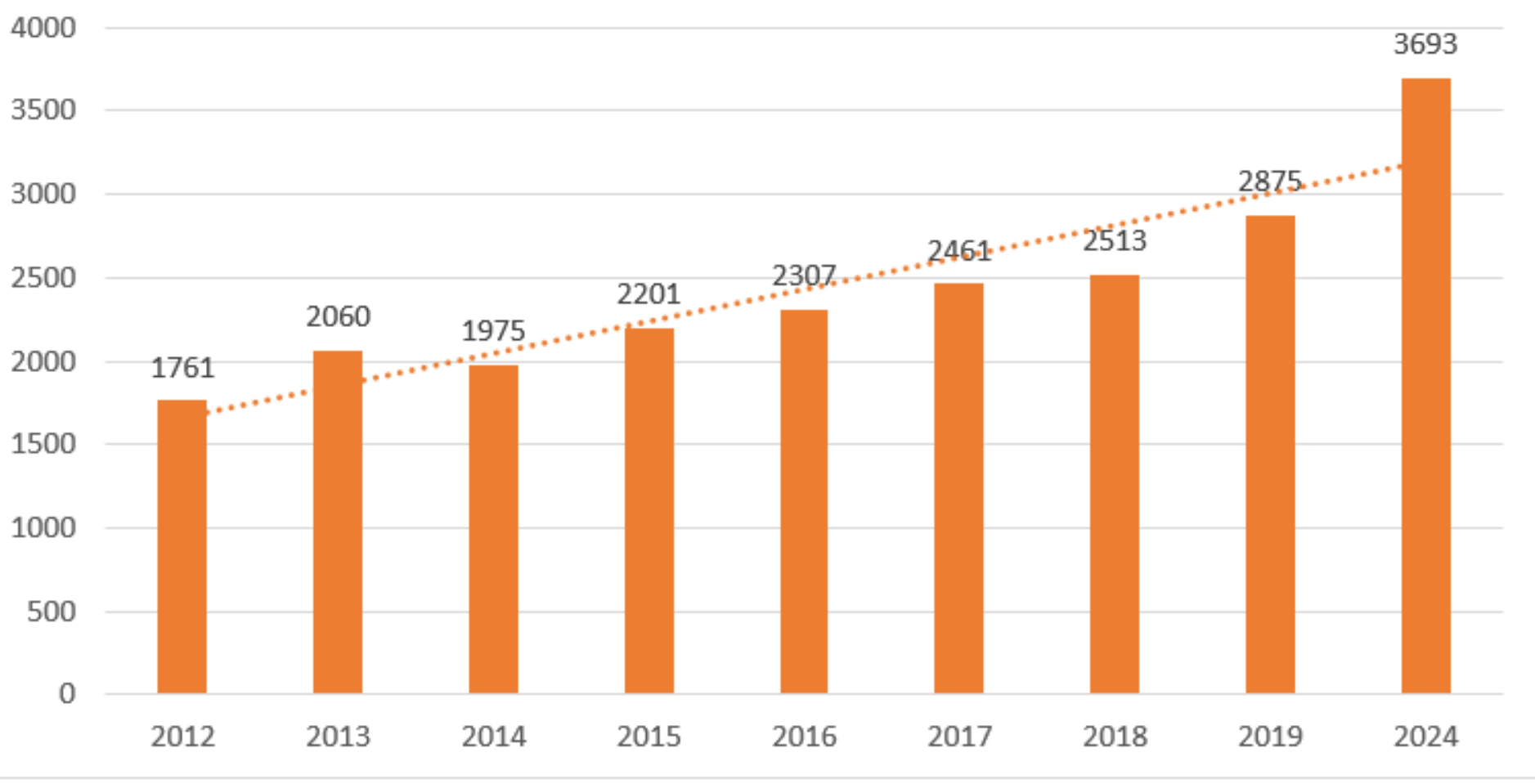

Figure 1

Growth of Islamic Financial Assets

Source: Note: 2024 is predicted data; In US \$ Billion

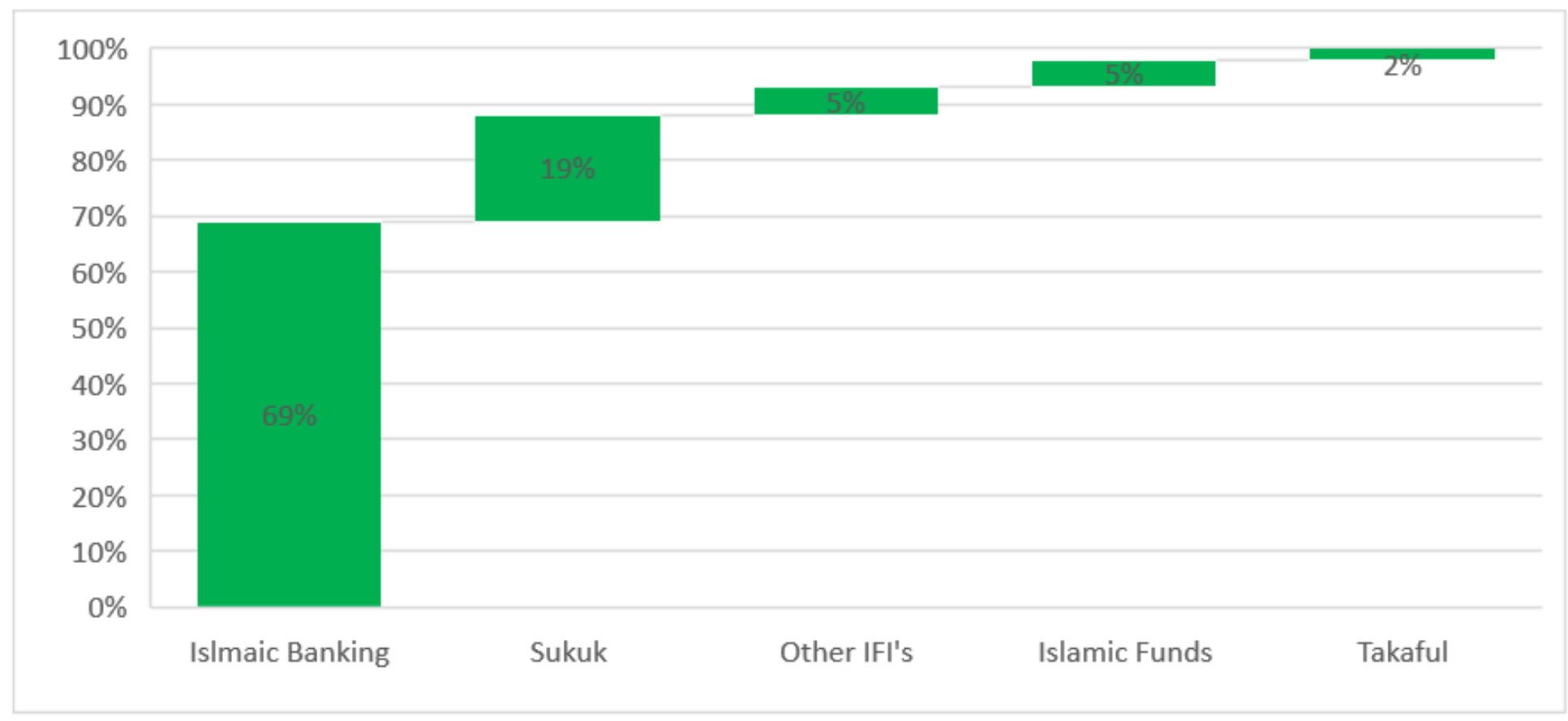

Figure 2 
Global Islamic Finance Asset distribution

IFDI-2020

low high

Figure 3
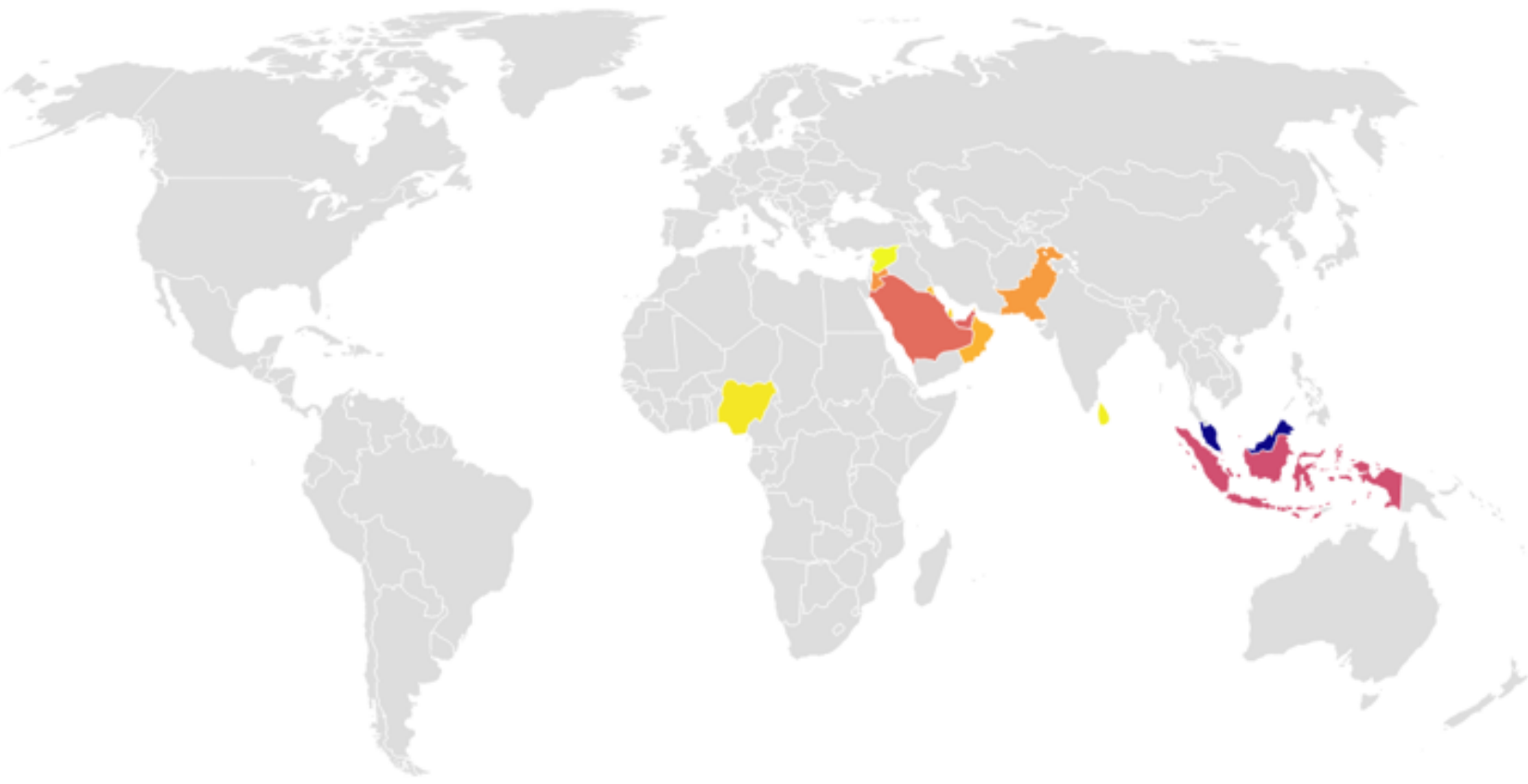

Global Islamic finance development indicator 


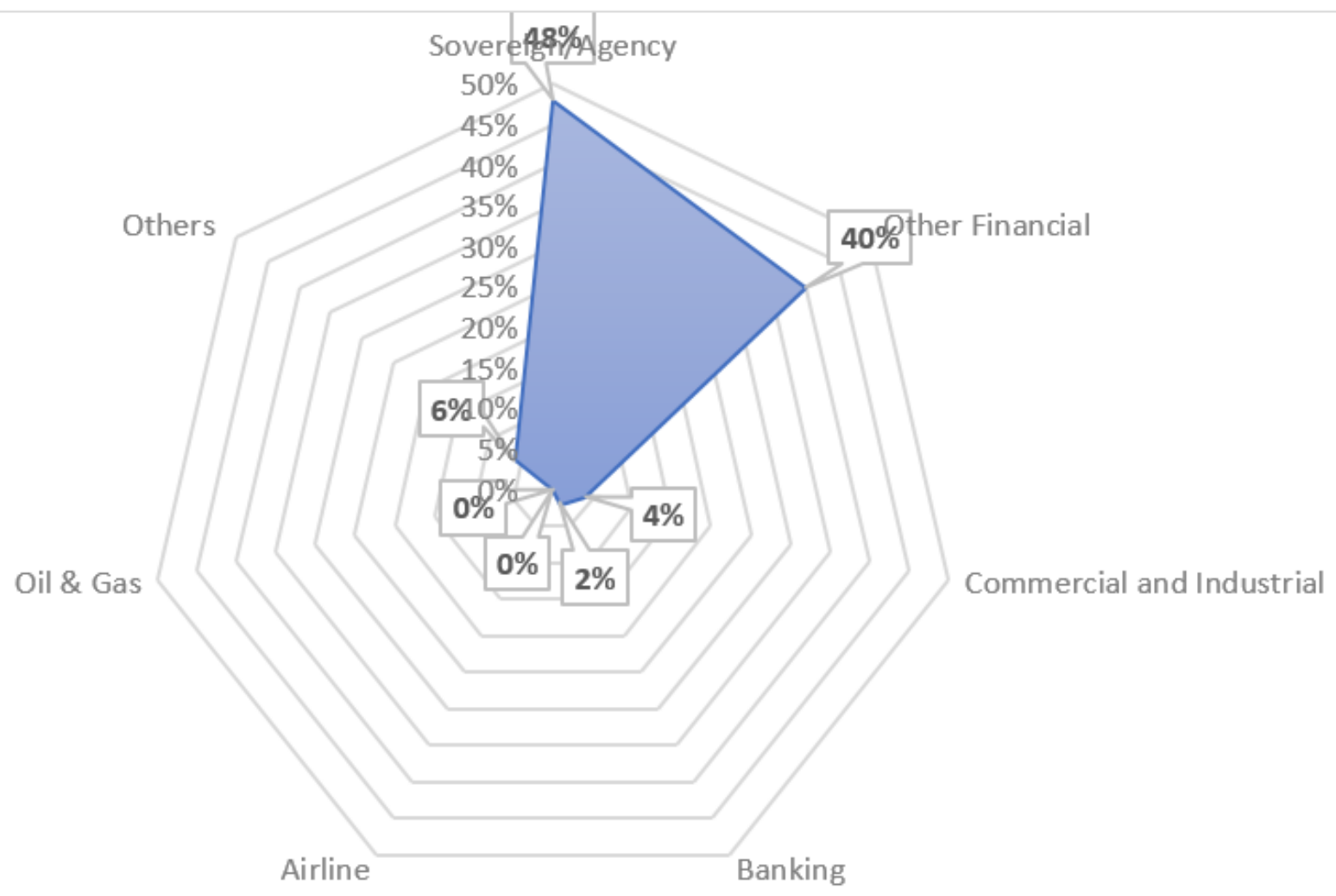

\section{Figure 4}

\section{Sukuk outstanding sector-wise}

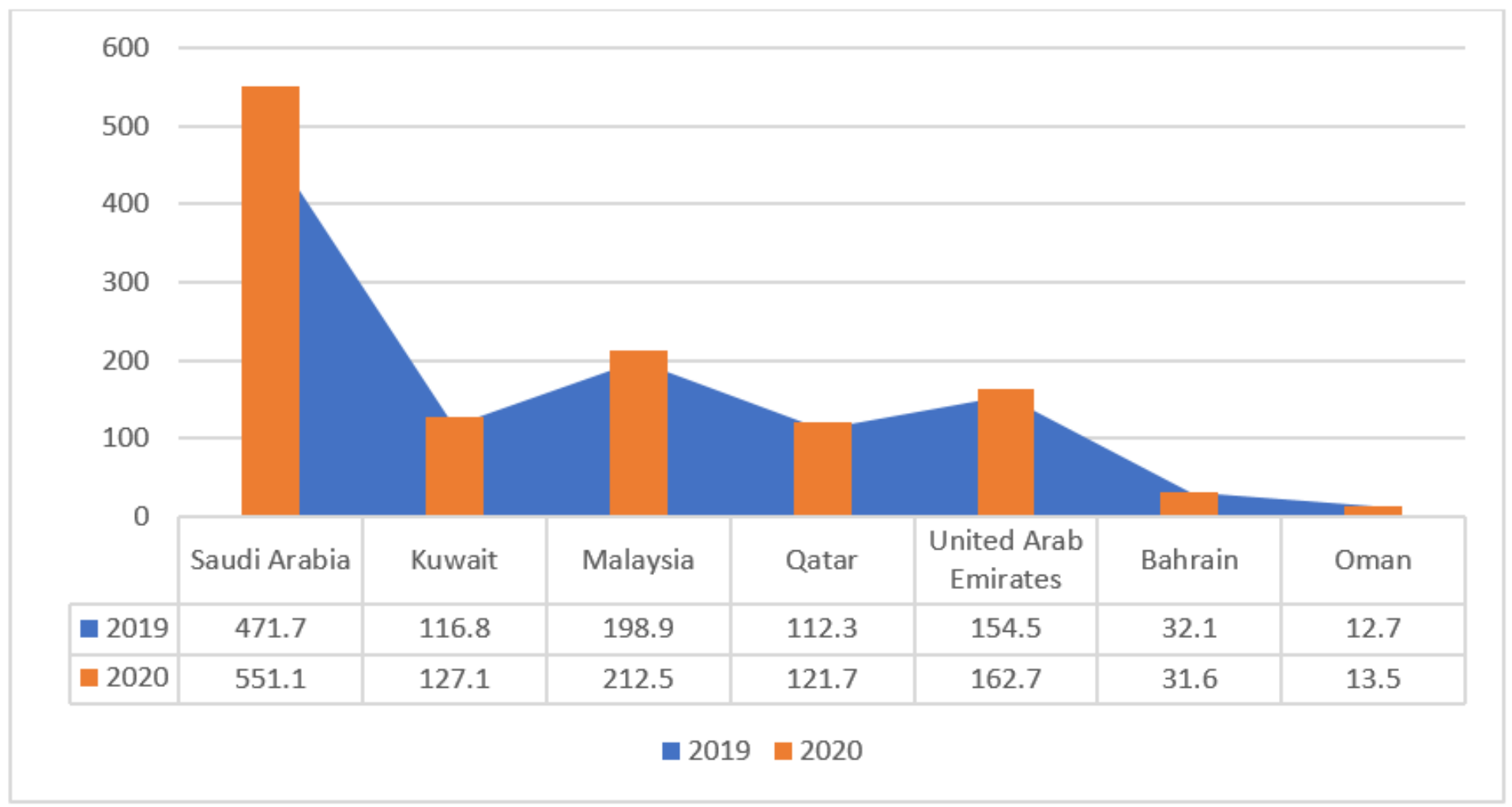


Figure 5

Islamic Banking Assets Share of total Banking Assets in Select Economies

\begin{tabular}{|c|c|c|c|c|}
\hline & Conventional & Islamic & Conventional & Islamic \\
\hline Saudi Arabia & 49.4 & 50.6 & -8.1 & 16.8 \\
\hline Kuwait & 57.5 & 42.5 & 0.5 & 8.8 \\
\hline Malaysia & 69.9 & 30.1 & 3.8 & 6.8 \\
\hline Qatar & 73.4 & 26.6 & 8.6 & 8.4 \\
\hline United Arab Emirates & 81.1 & 18.9 & 2.9 & 5.3 \\
\hline Bahrain & 84.8 & 15.2 & 1.7 & -1.5 \\
\hline Oman & 85.7 & 14.3 & 0.9 & 6.3 \\
\hline
\end{tabular}

Source: Central Banks of Saudi Arabia, Oman, UAE, Qatar, Malaysia, Kuwait, Bahrain • Created with Datawrapper

Figure 6

Islamic banking vs conventional banking Assets by Share and Asset by growth during Covid19 


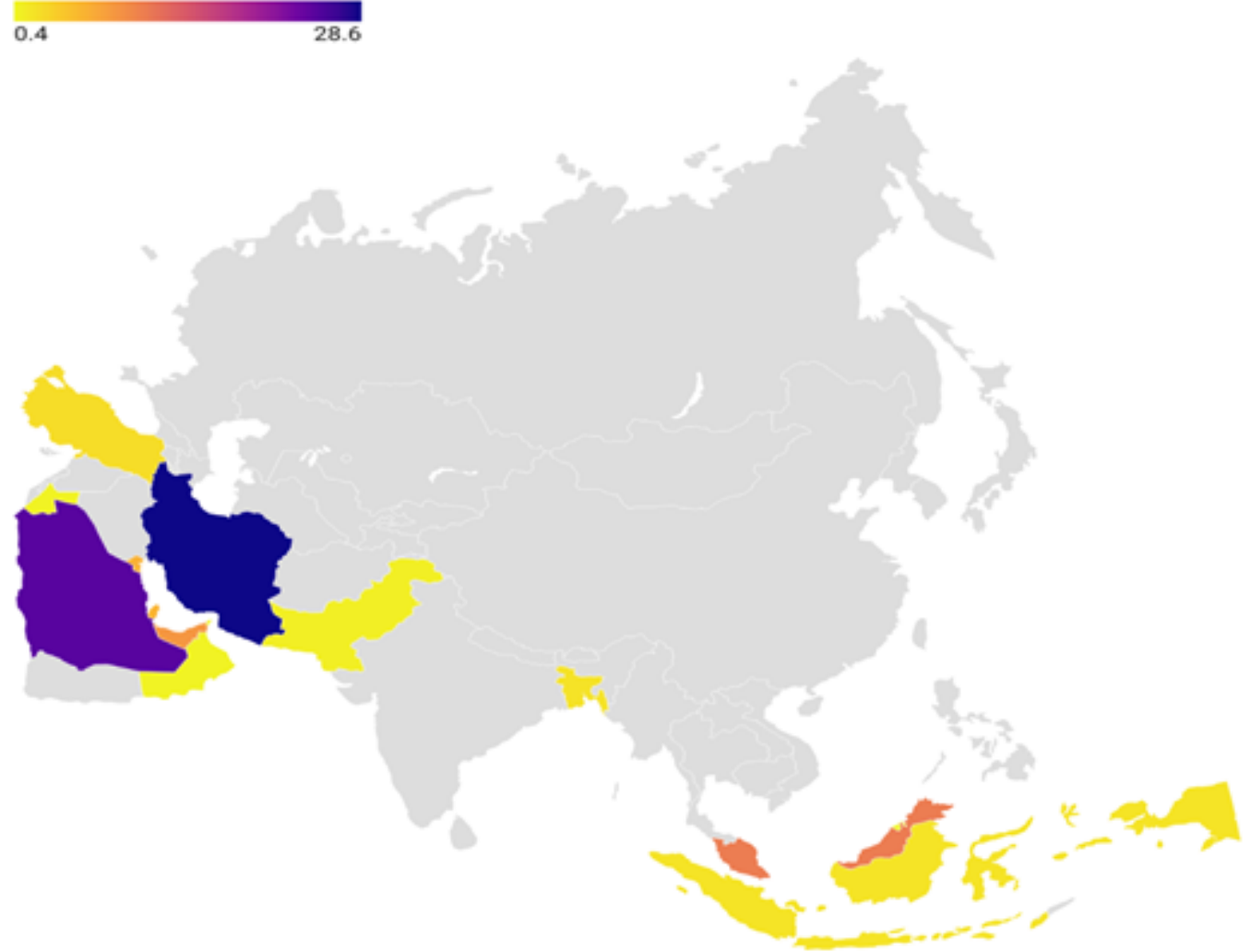

Source: IFSB Secretariat Workings - Created with Datawrapper

Figure 7

Global share of Islamic Finance and banking 


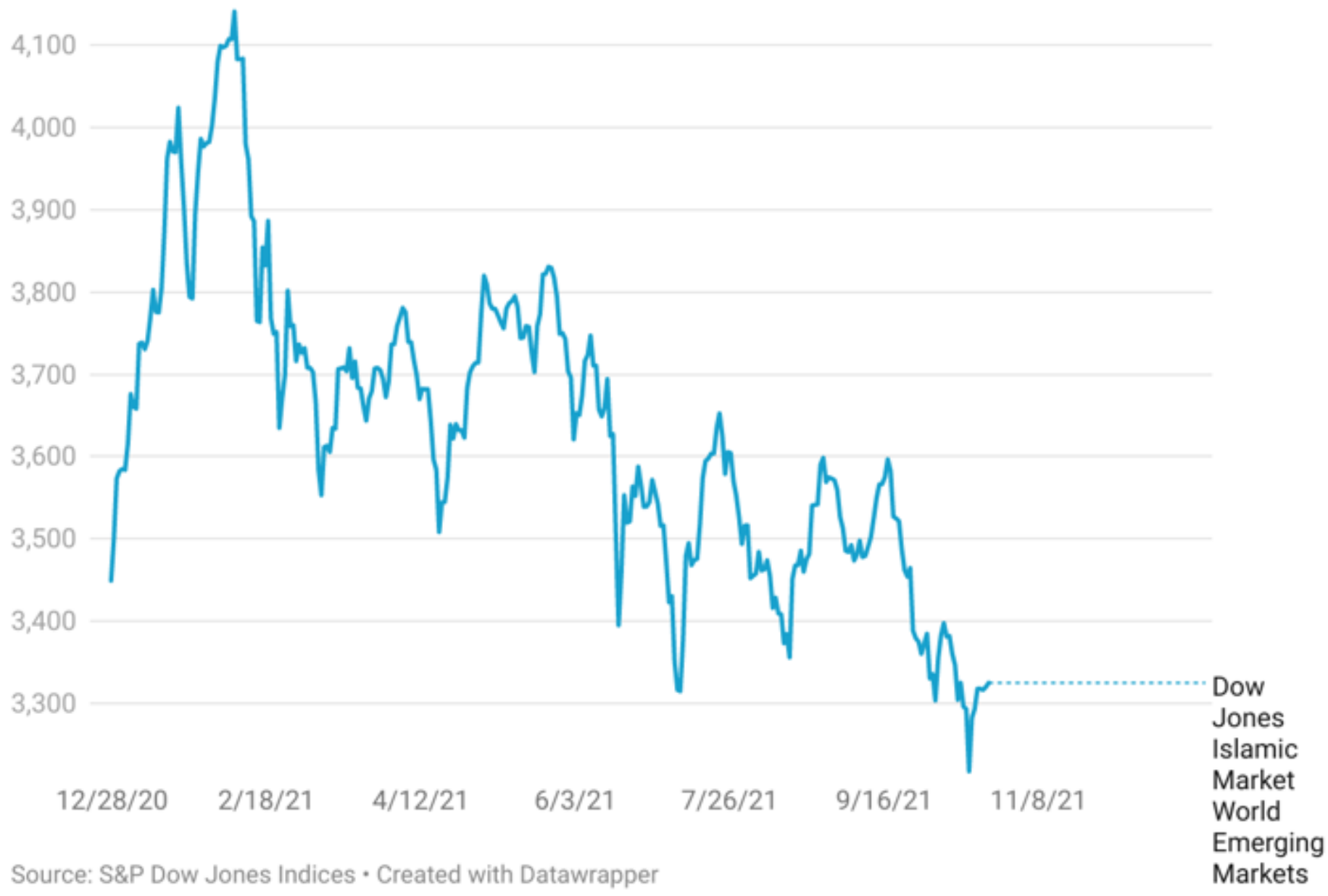

Figure 8

Islamic Equity Indices (2011-2021 YTD) 
S\&P Global 1200 Shariah

IT

Healthcare

Industrials

Consumer Discretionary

Communication Services

Consumer Staples

Materials

Energy

Real Estate

Financials

Utilities

Others

\section{4}

17

\section{1}

11

8.7

\section{5}

5.3

2

0.6

0.3

0
1.2
S\&P Global 1200

\section{2}

12.4

10.2

12.3

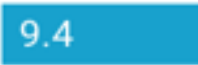

7.5

4.6

2.9

2.2

13.3

2.9

Source: S\&P Global $1200 \cdot$ Created with Datawrapper

Figure 9

Sector Breakdown 2020 